Portland State University

PDXScholar

\title{
Stream Temperature Management in the Tualatin Watershed: Is it Improving Salmonid Habitat?
}

Raymond Banks Hennings

Portland State University

Follow this and additional works at: https://pdxscholar.library.pdx.edu/geog_masterpapers

Part of the Nature and Society Relations Commons, and the Physical and Environmental Geography Commons

Let us know how access to this document benefits you.

\section{Recommended Citation}

Hennings, Raymond Banks, "Stream Temperature Management in the Tualatin Watershed: Is it Improving Salmonid Habitat?" (2014). Geography Masters Research Papers. 8.

https://pdxscholar.library.pdx.edu/geog_masterpapers/8

10.15760/geogmaster.07

This Paper is brought to you for free and open access. It has been accepted for inclusion in Geography Masters Research Papers by an authorized administrator of PDXScholar. Please contact us if we can make this document more accessible: pdxscholar@pdx.edu. 


\section{Stream Temperature Management in the Tualatin Watershed}

Is it improving salmonid habitat?

By

Raymond Banks Hennings

A research paper submitted in partial fulfillment of the requirements for the degree of

Master of Science

In

Geography

Committee:

Dr. Teresa Bulman, Advisor

Dr. Heejun Chang

Dr. Jiunn-Der Duh

Portland State University

November 24, 2014 


\section{Contents}

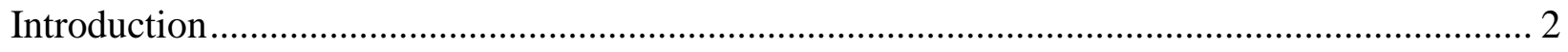

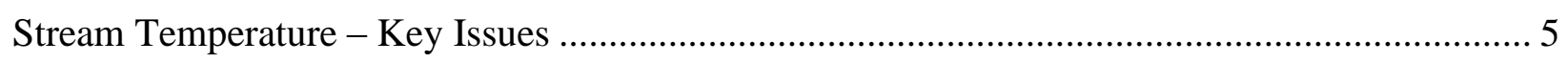

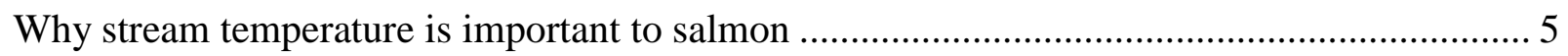

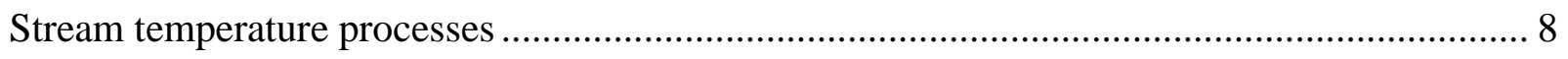

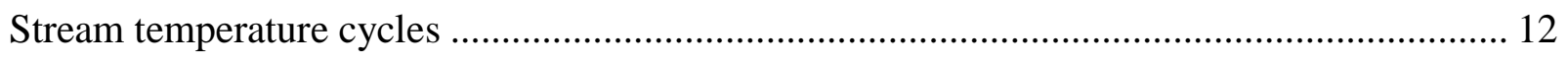

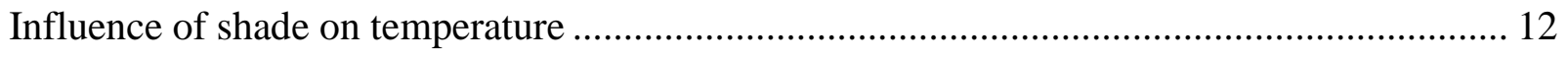

Influence of streamflow on temperature …………........................................................ 13

Human impacts on stream temperature ...................................................................... 14

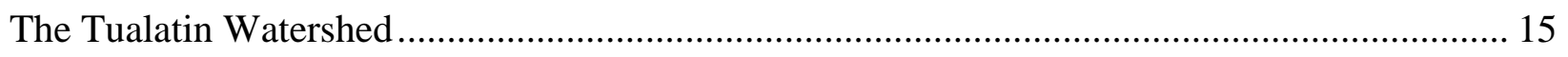

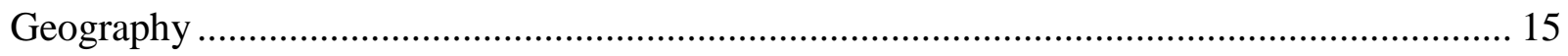

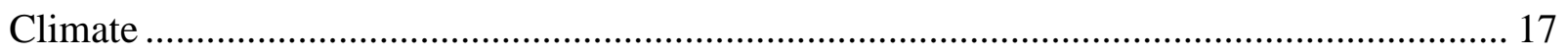

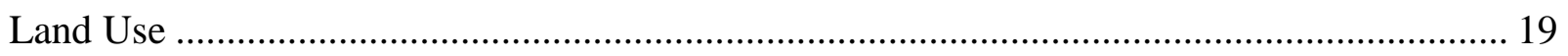

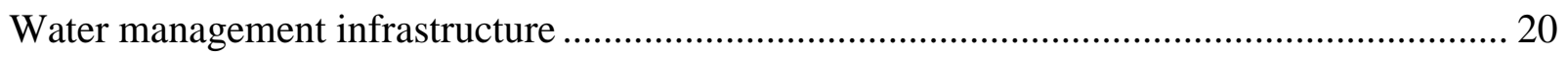

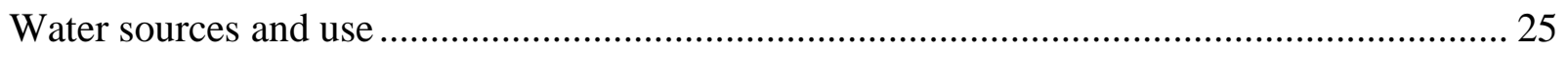

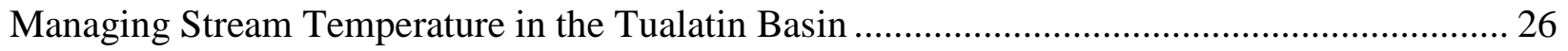

Tualatin basin temperature Total Maximum Daily Loads ..................................................... 26

Stream temperature criteria for the Tualatin basin............................................................... 28

Clean Water Services water quality trading program ………….......................................... 30

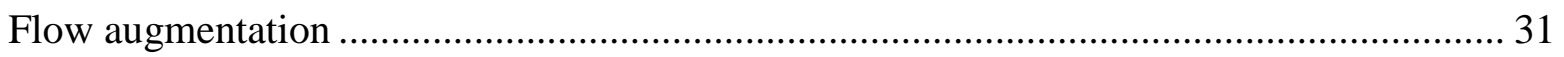

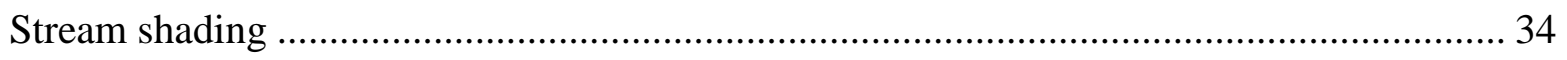

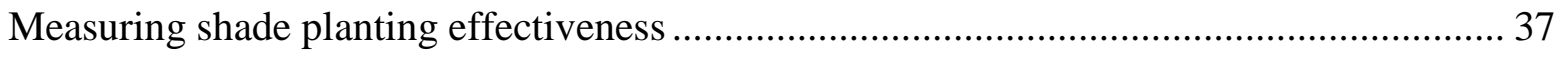

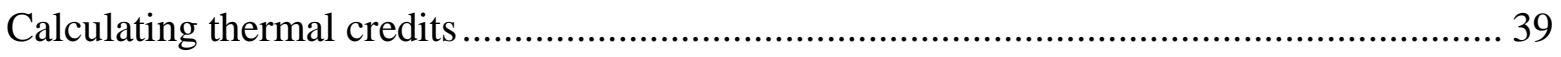

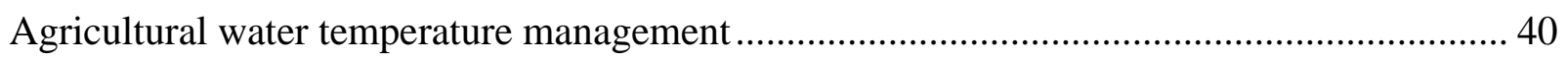

Forestry water temperature management ......................................................................... 41

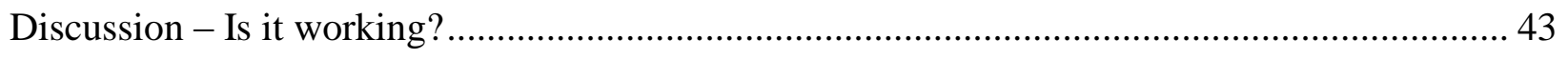

Summary

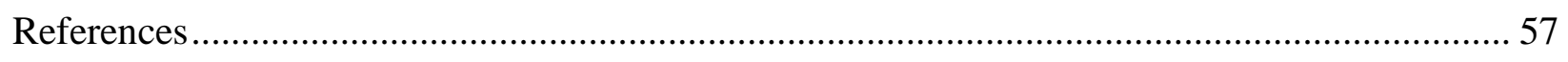

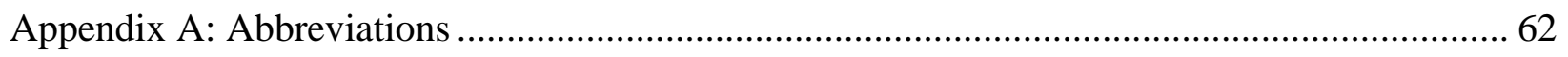

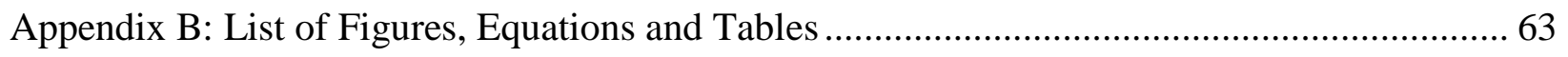

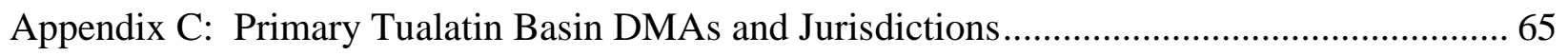




\section{Introduction}

The purpose of this paper is to examine the literature from scientific and governmental entities that describes the problems with elevated stream temperatures in the Tualatin basin, the actions being taken to resolve those problems, and to assess whether these actions are meeting the goal of improving salmonid habitat in the basin. Elevated stream temperatures are considered a pollutant under the US Clean Water Act (Clean Water Act 1972, as amended) because increased stream temperatures can be harmful to native aquatic biota, particularly salmonid fish species that have evolved to use cold water (IMST 2004).

The Tualatin basin contains a complex mix of land uses: Forested uplands, agricultural lowlands, and fast-growing urban areas (figure 1). It has a climate pattern that includes cool, wet winters and dry, warm summers. Responsibility for managing stream temperature is shared by several entities, and many stream temperature management efforts are underway in the basin. This watershed has been chosen for study because a novel, watershed-based approach is being used in the region to address water quality issues. 


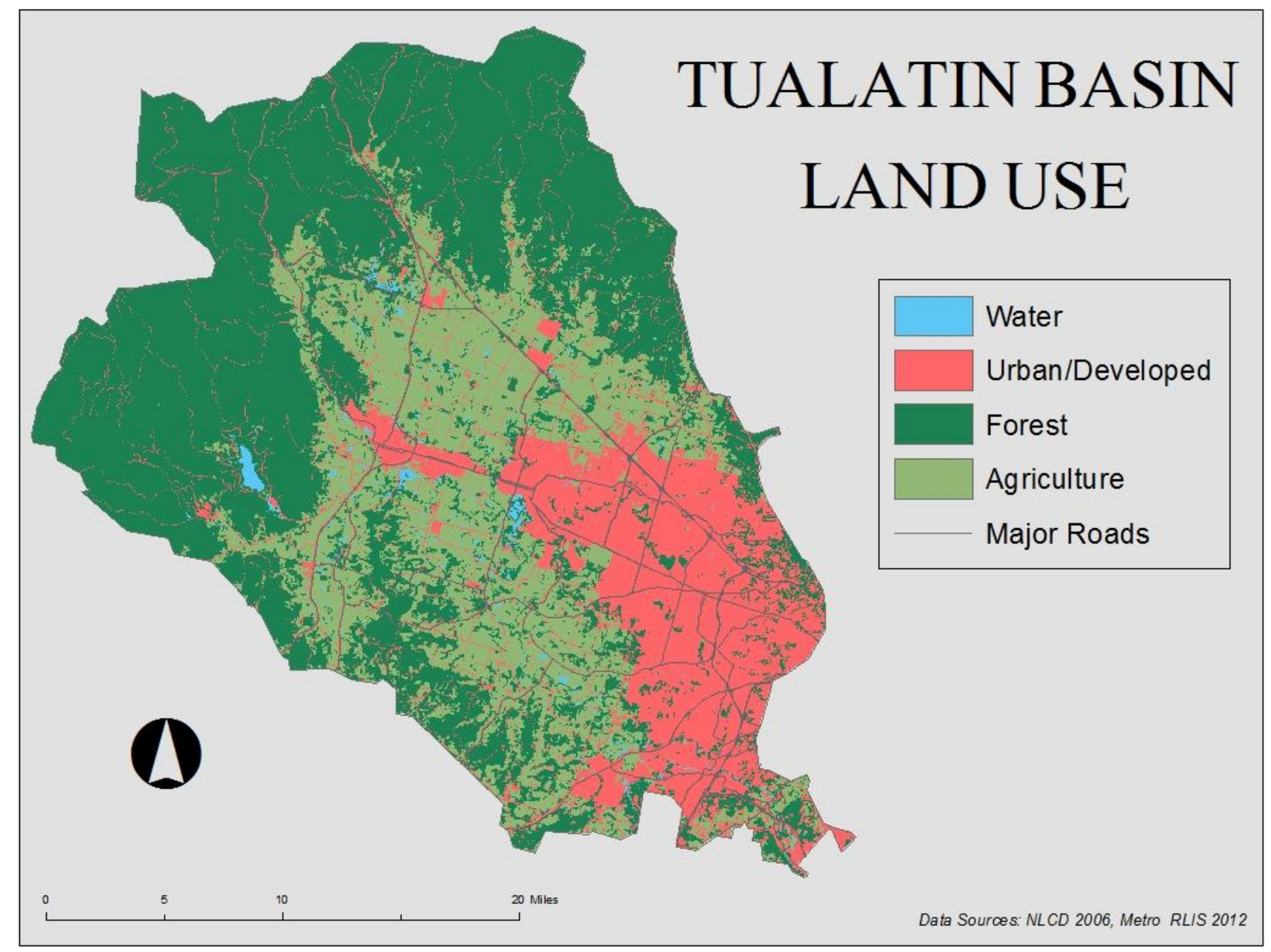

Figure 1: Tualatin basin land use (Sources: Fry et al. 2011, Metro 2012)

Nearly 200 miles of stream reaches in the Tualatin basin are listed as impaired for water temperature by the Oregon Department of Environmental Quality (DEQ) (DEQ 2014a). The main legal drivers for managing stream temperature in the Tualatin basin are the Clean Water Act and the Endangered Species Act (Endangered Species Act 1973, as amended). The DEQ is responsible for enforcing the provisions of the Clean Water Act, and it has established rules for permissible stream temperatures throughout Oregon. 
Clean Water Services (CWS) is the sewer and surface water management agency responsible for the urban portion of the Tualatin basin. It operates four wastewater treatment facilities (WWTFs), two of which release warmed effluent into the Tualatin River. It was granted Oregon's first watershed-based National Pollutant Discharge Elimination System (NPDES) permit, which allows it to use a combination of streamflow augmentation and riparian shade planting to mitigate elevated stream temperatures from WWTF effluent releases (DEQ 2004).

The Oregon Department of Agriculture (ODA) is responsible for managing pollution from agricultural sources in Oregon, using rules established under the Agricultural Water Quality Management Act (Oregon Agricultural Water Quality Management Act 1993, as amended). Farmers must maintain a vegetated streamside buffer; planting for stream shading is encouraged (ODA 2010).

The Oregon Department of Forestry (ODF) is responsible for rules regulating pollution from forest harvest. Administrative rules developed under the state's Forest Practices Act (FPA) govern harvest activities on private timberlands, while the Oregon State Forest Management Plan (FMP) regulates operations in state-owned forests. These rules include standards for no-cut buffers around streams to reduce pollution from runoff and to protect riparian habitat, including cool stream temperatures (ODF 2010).

This paper will examine some of the key issues surrounding stream temperature: why managing temperature is important, the processes that influence stream temperatures, the human impact on water temperatures, and tools being used to manage the problem. The following section will describe the attributes of the watershed, including geography, climate, land use and water management infrastructure and use. The paper will then review the actions being taken to 
manage Tualatin basin stream temperatures, followed by an analysis of the effectiveness of the watershed-based approach to managing stream temperatures and a look at issues that could affect stream temperatures in the future.

\section{Stream Temperature - Key Issues}

This section explains the importance of stream temperature to salmonids, the factors that influence stream temperature and how human activities impact stream temperature.

Stream temperatures in the Tualatin basin are influenced by streamflow and solar radiation. Temperatures can be higher than optimum for salmonids during summer, when solar radiation is highest and streamflow is lowest. Human activity in the basin, including warm water releases, removal of streamside vegetation, alteration of stream hydrology and water withdrawals, can all contribute to elevated stream temperatures (IMST 2004). On a larger scale, human-caused climate change could influence stream temperatures by altering existing patterns of precipitation and air temperature (Isaak et al. 2001).

\section{Why stream temperature is important to salmon}

Salmonids have evolved over millions of years along with the landscape they inhabit, and they were present in high numbers in Pacific Northwest streams prior to European contact. Salmon populations have declined dramatically in response to human changes to the landscape starting in the 1800s. These anthropogenic changes have occurred at a pace greater than the salmonids ability to adapt (IMST 2004). 
All fish species have an optimum temperature range for survival, growth and reproduction. Elevated water temperatures can affect salmon during all stages of their lifecycle. While cold water fish such as salmon may survive temperatures higher than the optimum, exposure to high temperatures may compromise their growth, reproduction, feeding, ability to compete, resistance to predation and resistance to disease and stress. The effect of elevated temperatures on salmonid mortality varies with temperature (table 1).

Table 1: Physiological effects of elevated temperatures on fish (Source: DEQ 2001)

\begin{tabular}{|c|c|c|}
\hline Modes of Thermally Induced Fish Mortality & $\begin{array}{c}\text { Temperature } \\
\text { Range }\end{array}$ & $\begin{array}{c}\text { Time to } \\
\text { Death }\end{array}$ \\
\hline $\begin{array}{c}>90^{\circ} \mathrm{F} \\
>32^{\circ} \mathrm{C}\end{array}$ & Instantaneous \\
\hline Instantaneous Lethal Limit - Denaturing of bodily enzyme & $\begin{array}{c}70^{\circ} \mathrm{F}-77^{\circ} \mathrm{F} \\
\text { systems }\end{array}$ & Hours to Days \\
\hline $\begin{array}{c}\text { Incipient Lethal Limit - Breakdown of physiological regulation of } \\
\text { vital bodily processes, namely: respiration and circulation }\end{array}$ & $21^{\circ} \mathrm{C}-25^{\circ} \mathrm{C}$ \\
\hline $\begin{array}{c}\text { Sub-Lethal Limit - Conditions that cause decreased or lack of } \\
\text { metabolic energy for feeding, growth or reproductive behavior, } \\
\text { encourage increased exposure to pathogens, decreased food } \\
\text { supply and increased competition from warm water tolerant } \\
\text { species }\end{array}$ & $\begin{array}{c}64^{\circ} \mathrm{F}-74^{\circ} \mathrm{F} \\
17.8^{\circ} \mathrm{C}-23^{\circ} \mathrm{C}\end{array}$ & $\begin{array}{c}\text { Weeks to } \\
\text { Months }\end{array}$ \\
\hline$\quad$
\end{tabular}

The life cycle of anadromous salmonids begins in fresh water. Salmon eggs mature into alevin that feed from an attached yolk sac. After the yolk sac is consumed, salmonids grow through a series of juvenile stages. Alevin develop into fry, which feed on plankton; fry become parr, which feed on macroinvertebrates; parr mature into smolts, which undergo the physiological changes that allow ocean migration. After several years at sea, adults return to freshwater to spawn and die (figure 2). Elevated stream temperatures can affect salmonids at all life cycles (McCullough 1999). 


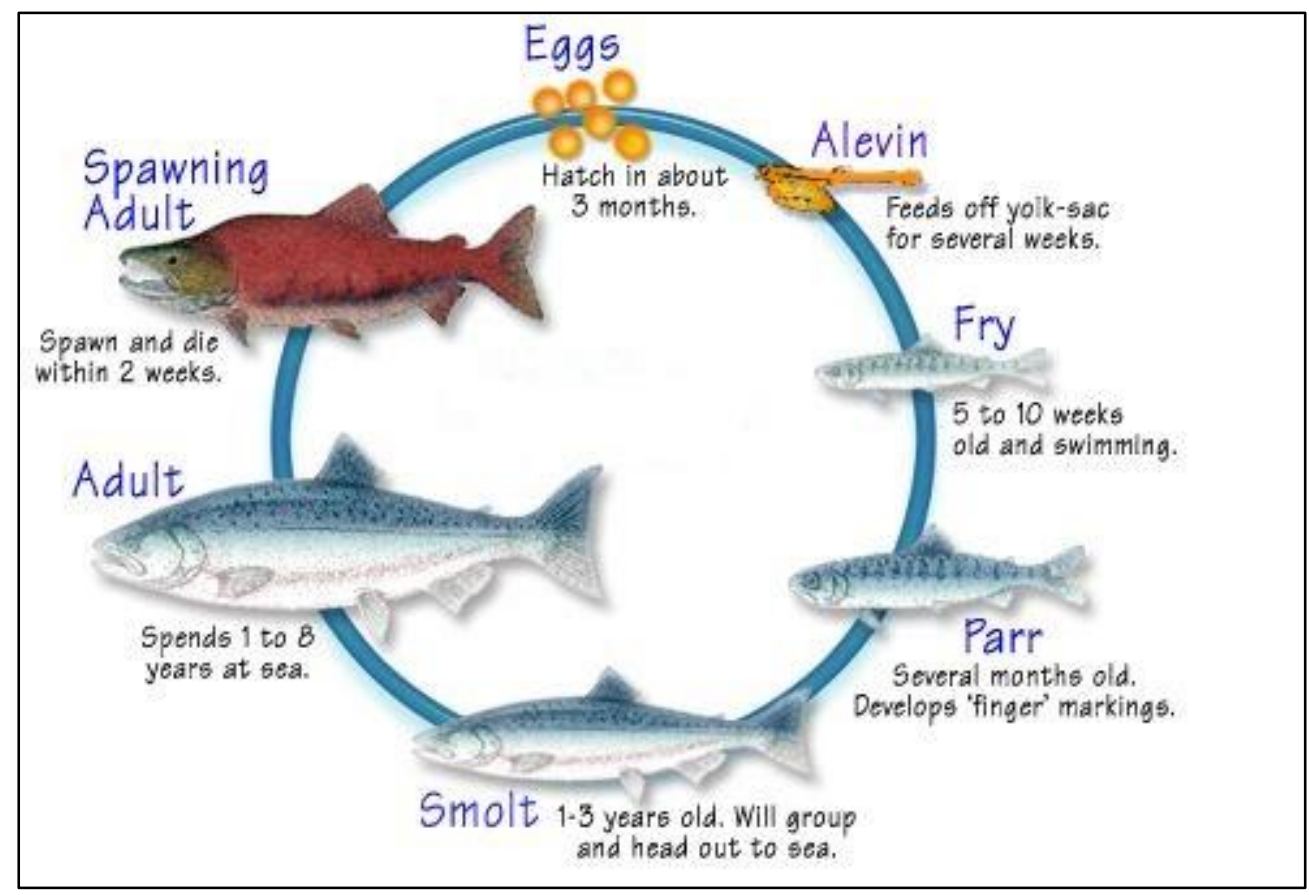

Figure 2: Salmon Life Cycle (Source: FishEx 2014)

Survival of eggs and alevin require an ample supply of dissolved oxygen, but warmer temperatures decrease the capacity of water to hold dissolved oxygen. Higher temperatures also increase productivity and nutrient cycling in aquatic systems, increasing competing in-stream demands for oxygen (IMST 2004).

Timing of fry emergence in some watersheds has evolved so that food resources are available when needed by fry. Elevated temperatures can disrupt this synchrony by influencing the timing of fry emergence (Bjornn and Reiser 1991). Salmonids hatching in warmer water often have a shorter incubation period than those hatching in cooler water, and are larger as smolts compared to those from cooler waters. These larger smolts tend to migrate at a younger age and their migration and ocean survival rate can be lower than smolts that develop longer in fresh water (Holtby 1988). 
Water temperatures can also affect the growth rate of juvenile salmon. Higher temperatures increase metabolic activity, increasing energy needs. If temperatures are above optimum, growth rates tend to decline, because the cost of foraging and digestion can be greater than the energy received from food (IMST 2004). Slow growth can have a delayed impact at later life stages because smaller juvenile salmonids have a higher mortality rate than larger juveniles (Beauchamp 2009).

Warm water favors pathogens that can infect salmonids and can lower their resistance to infection (Materna 2001). Warmer water can cause fish to congregate in cold-water refugia, contributing to the spread of disease (IMST 2004). Warmer temperatures can also result in increased predation from other fish species. Higher temperatures favor warm-water predators, and thermal stress experienced by salmonids can increase their vulnerability to predation (Sauter et al. 2001).

High water temperatures can limit the success of adult migration and spawning. Warm temperatures encountered en route to spawning habitat can slow or block migration, decreasing survival rate and altering the timing of adults returning to spawn (McCullough et al. 2001). In addition, elevated temperatures can affect both the ability to spawn and the viability of the eggs produced (McCullough 1999).

\section{Stream temperature processes}

One of the primary drivers of stream temperature is exchange of heat with the atmosphere, which includes solar radiation, thermal (longwave) radiation, evaporation, convection, and conductance. All of these processes can heat or cool a stream except for solar radiation, which can add heat energy but cannot cool a stream (Boyd and Sturdevant 1997) (figure 3). 


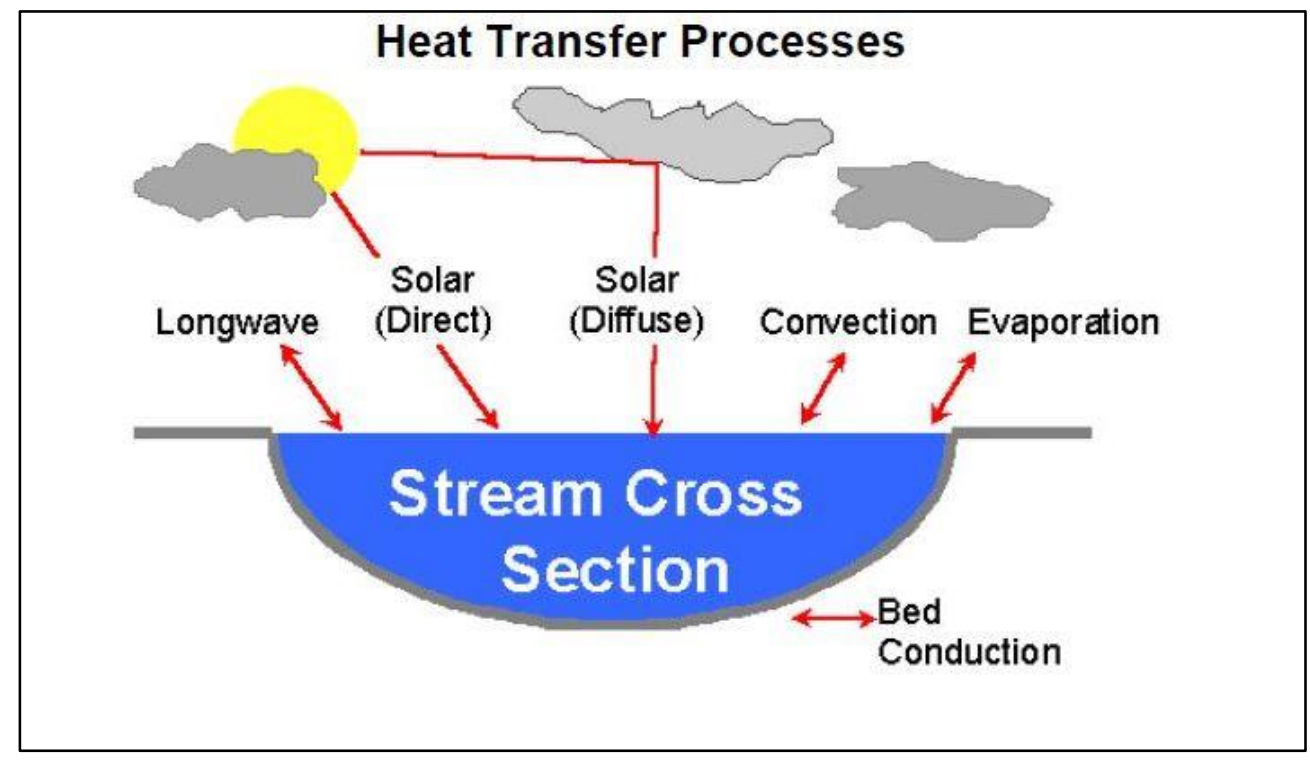

Figure 3: Heat Transfer Processes (Source: Boyd and Sturdevant 1997)

The direction of heat energy will depend on the temperature difference between the stream and the objects it is in contact with. When objects of different temperatures contact each other, heat will flow from the warmer to the cooler object. Stream temperatures are affected by six heat transfer processes.

Solar radiation is the most significant process that affects summer stream temperatures. Solar radiation can be diffuse (scattered in the atmosphere before reaching the surface of the earth), or direct (striking the stream surface unobstructed). Direct solar radiation can be attenuated by shade provided by topographic features and streamside vegetation.

Longwave (thermal) radiation is heat energy coming from objects: heat energy can be provided regardless of the presence of solar radiation. Objects near the stream that are warmer 
than the water add heat energy to the stream. If the surrounding environment is cooler, longwave radiation will release heat energy from the stream.

Convection exchanges heat energy between surfaces that contact each other. Streams are in contact with the air immediately above the surface. If the air is warmer than the water, heat energy is added to the stream; if the water is warmer, heat energy is released from the stream.

When water molecules are heated, they can change into water vapor. This process requires heat energy, so evaporation results in stream cooling. Air movement can support the evaporation process by removing water vapor from the stream surface.

In shallow streams, streambed conductance can be a source of heat energy. As the water is warmed, heat energy can be absorbed by the streambed. Conductance is influenced by streambed composition. A large surface area of streambed in contact with the water will increase the heat exchange potential.

Total energy flux is the sum of the processes that affect stream heating and cooling. A positive total energy flux results in stream warming, while a negative energy flux will cool the stream (Boyd and Sturdevant 1997).

Solar flux (radiation) is the largest factor causing warming of an unshaded stream, especially midday when radiation is most direct. Some heat energy is offset by heat loss due to evaporation and longwave radiation, but the magnitude of the heat loss is less than the heat energy gained from solar radiation, so water temperature increases. The other heat transfer processes can also supply heat energy to a stream, but to a lesser degree than solar radiation (figure 4). 


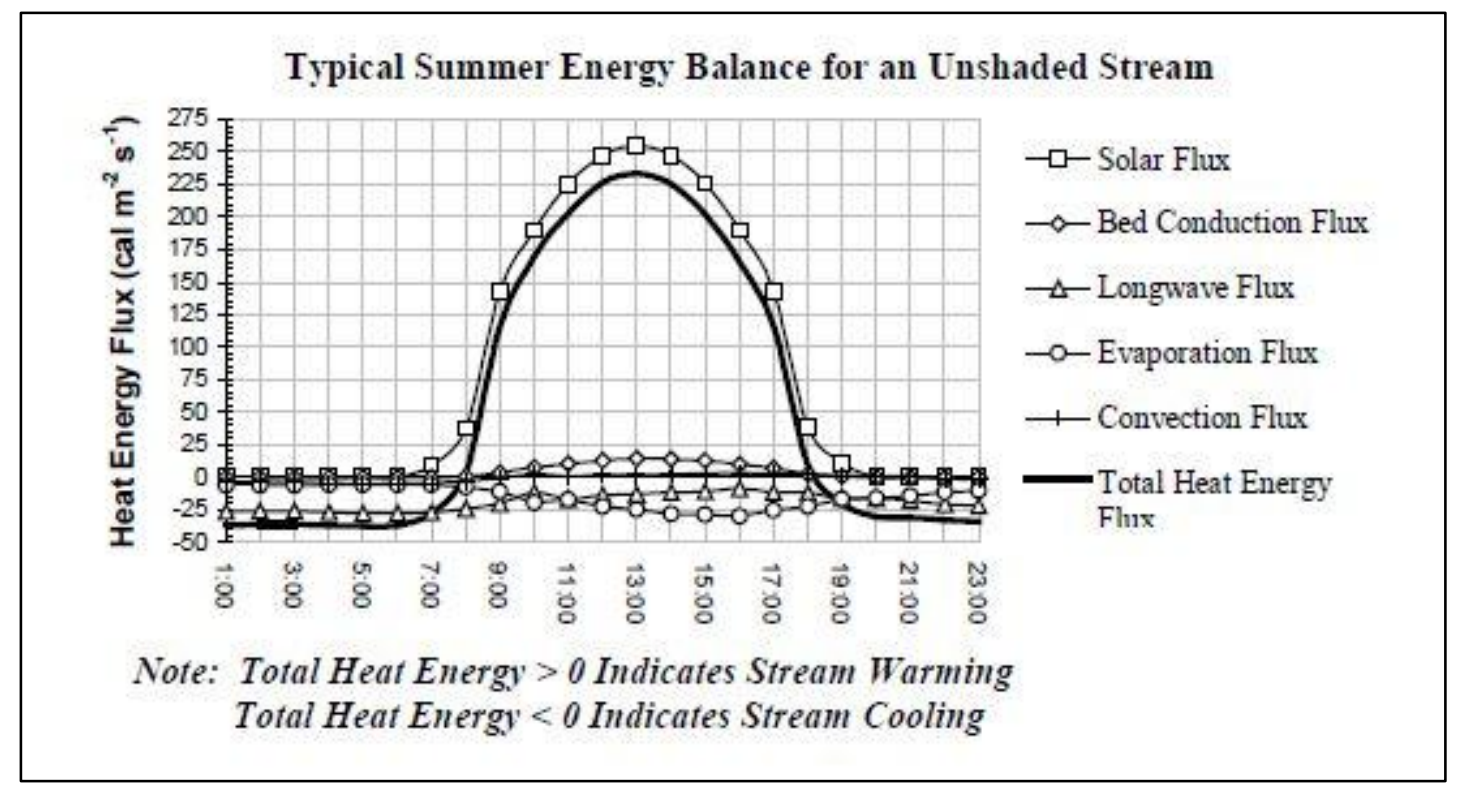

Figure 4: Energy balance for an unshaded stream (Source: Boyd and Sturdevant 1997)

Evaporation, back radiation (longwave radiation from the stream), and convection can cool streams. The cooling rate is influenced by air and stream temperature differences, vapor pressure deficit and wind (Boyd and Sturdevant 1997) (figure 5).

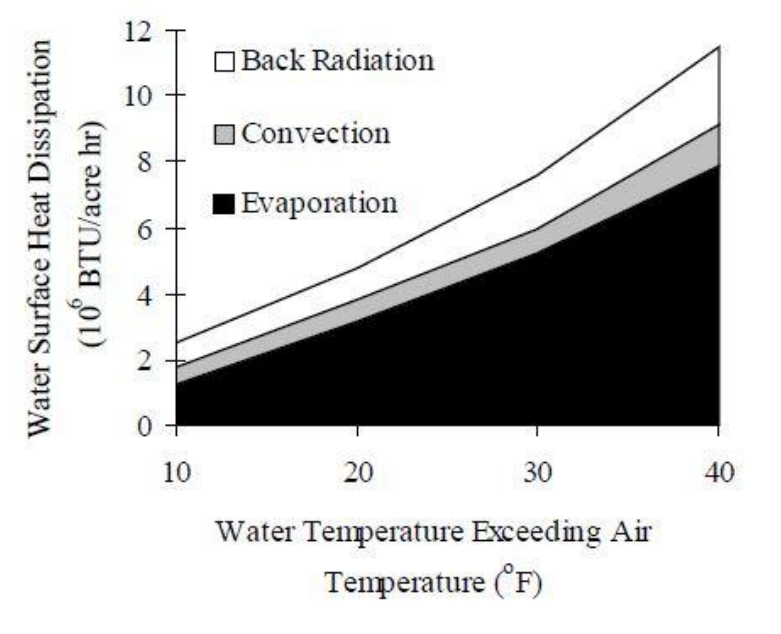

Figure 5: Stream Cooling Processes (Source: Boyd and Sturdevant 1997) 
Groundwater exchange (hyporheic flow) between the stream and an adjacent aquifer can influence stream temperature. Groundwater augments streamflow where it enters the stream and reduces streamflow when water returns to the aquifer. Summer groundwater temperatures are usually lower than stream temperatures, so incoming hyporheic flow that increases streamflow often reduces stream temperature. Streams can also be warmed or cooled by the temperature of tributaries (Poole and Berman 2001).

\section{Stream temperature cycles}

Streams follow both a seasonal and a diurnal cycle (Sinokrot and Stefan 1993). Stream temperatures tend to follow air temperatures throughout the year while the daily cycle is driven primarily by heat energy exchange with the atmosphere. Stream temperatures tend to increase in the downstream direction, but can be modified by groundwater inflow, irrigation return, reservoir releases and wastewater discharges. Stream temperatures are likely to be highest during summer when solar radiation is highest and streamflow is lowest (Boyd and Sturdevant 1997).

\section{Influence of shade on temperature}

Shade cannot physically cool a stream, but it can moderate its temperature by reducing the amount of solar radiation received. Shade duration and density are the most important controls on the quantity of solar radiation a stream accumulates.

The vertical position of the sun in the sky is its solar altitude, and the angle of the top of the shade to the centerline of the stream is the vegetation shade angle. When the solar altitude exceeds the vegetation shade angle, the stream is receiving direct solar energy (Boyd and 
Sturdevant 1997) (figure 6). The planting density and width of streamside vegetation buffers affect the quality of shading supplied to the stream; increasing density and width will lower incoming solar radiation. Solar heat loading can also be influenced by the stream's aspect (direction in relation to sun movement), latitude, time of day, and day of the year (CWS 2005a).

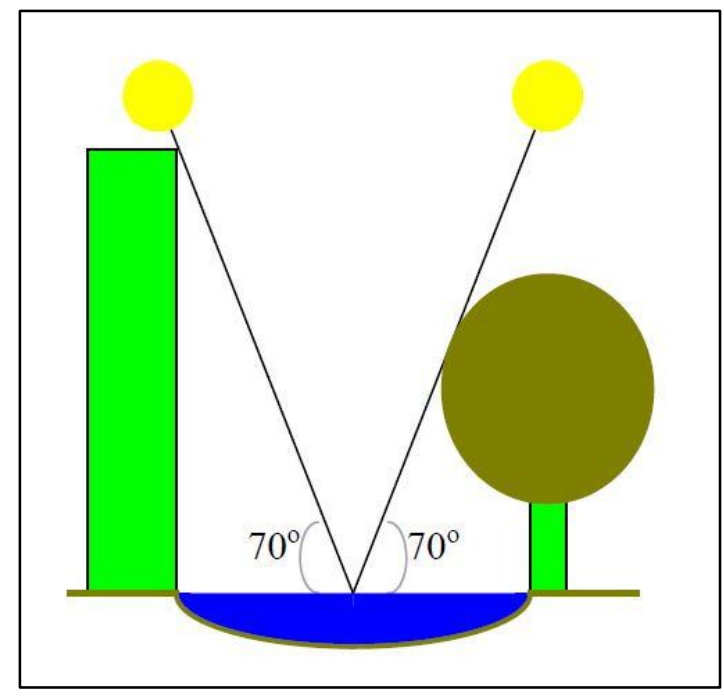

Figure 6: A 70 degree vegetation shade angle (Source: Boyd and Sturdevant 1997)

Channel geometry can affect the amount of heat energy a stream receives. Wider streams create a greater surface area for heat exchange; riparian vegetation often cannot shade the entire channel. Shallow streams may allow a greater amount of heat energy to reach the streambed, increasing streambed conductance (Boyd and Sturdevant 1997).

\section{Influence of streamflow on temperature}

Changes in stream temperature are the product of the increase in heat energy received divided by the volume of water receiving the heat energy (equation 1). If the processes that supply heat energy to a stream remain relatively stable, a stream with low streamflow will absorb more heat energy per unit volume of water than one with a higher streamflow. Increasing 
streamflow can help mitigate the effects of the stream heating processes (DEQ 2001). Flow augmentation can increase flow velocity, which reduces the amount of time water in a stream segment is exposed to solar radiation (CWS 2005a).

Equation 1: Stream temperature change equation (Source: DEQ 2001)

\section{$\Delta$ Temperature $\propto \frac{\Delta \text { Heat Energy }}{\text { Volume }}$}

\section{Human impacts on stream temperature}

Humans affect stream temperatures by altering channel morphology, streamflow, hyporheic exchange and riparian vegetation. The interaction of these factors is interrelated. Specific reach, stream and watershed conditions can change the influence of each of these factors on stream heating and cooling (IMST 2004).

Human activities and land management practices can influence stream temperature changes through a number of processes that affect heat energy transfer to streams or decrease streamflow. Removal of streamside vegetation through timber harvest, agricultural activities and urban development can increase the amount of direct solar radiation received by the stream. Withdrawals of water directly from streams, removing water from aquifers with wells, and restricting flow with dams can all decrease streamflow. Water returned to the stream, including effluent from manufacturing and wastewater treatment, irrigation return flow, and dam discharges can also affect stream temperatures and streamflow. All of these actions can reduce groundwater exchange (Naiman et al. 2005). 
Dams can affect stream temperature in several ways. Release of water from reservoirs can directly affect downstream temperatures by increasing discharge. If the release is from cooler water near the bottom of the reservoir (hypolimnetic release), this will tend to cool water downstream of the release site. Increasing discharge will dilute the heat energy contained in the stream, and will tend to push the temperature trend of the channel downstream toward the temperature of the release. However, flow regimes that are regulated by dams can dampen variation in flow and temperature, reducing the effectiveness of hyporheic flow as a temperature buffer. Dams can also disrupt the movement of sediments downstream of the dam, which can result in channel scouring and downcutting, reducing hyporheic exchange (Angilletta et al. 2008).

\section{The Tualatin Watershed}

This section will describe the geography and climate of the Tualatin basin, and examine land use patterns, existing water management infrastructure, and the sources and uses of water in the basin.

\section{Geography}

The Tualatin watershed, located west of Portland, Oregon, is an oval-shaped basin about 65 miles long and up to 40 miles wide, that drains approximately 712 square miles before joining the Willamette River at West Linn. Basin elevations range from nearly 3,000 feet in the coast range to about 60 feet at the mouth of the Tualatin River. Significant uplands in the basin include the Oregon Coast Range to the west, the Tualatin Mountains on the north, and Chehalem and Parret mountains to the south. Major cities in the basin include Forest Grove, Cornelius, 
Hillsboro, Beaverton, Tigard, Sherwood and Tualatin. Important tributary streams include Scoggins Creek, Gales Creek, Dairy Creek, Rock Creek and Fanno Creek (Risley 1997) (figure 7).

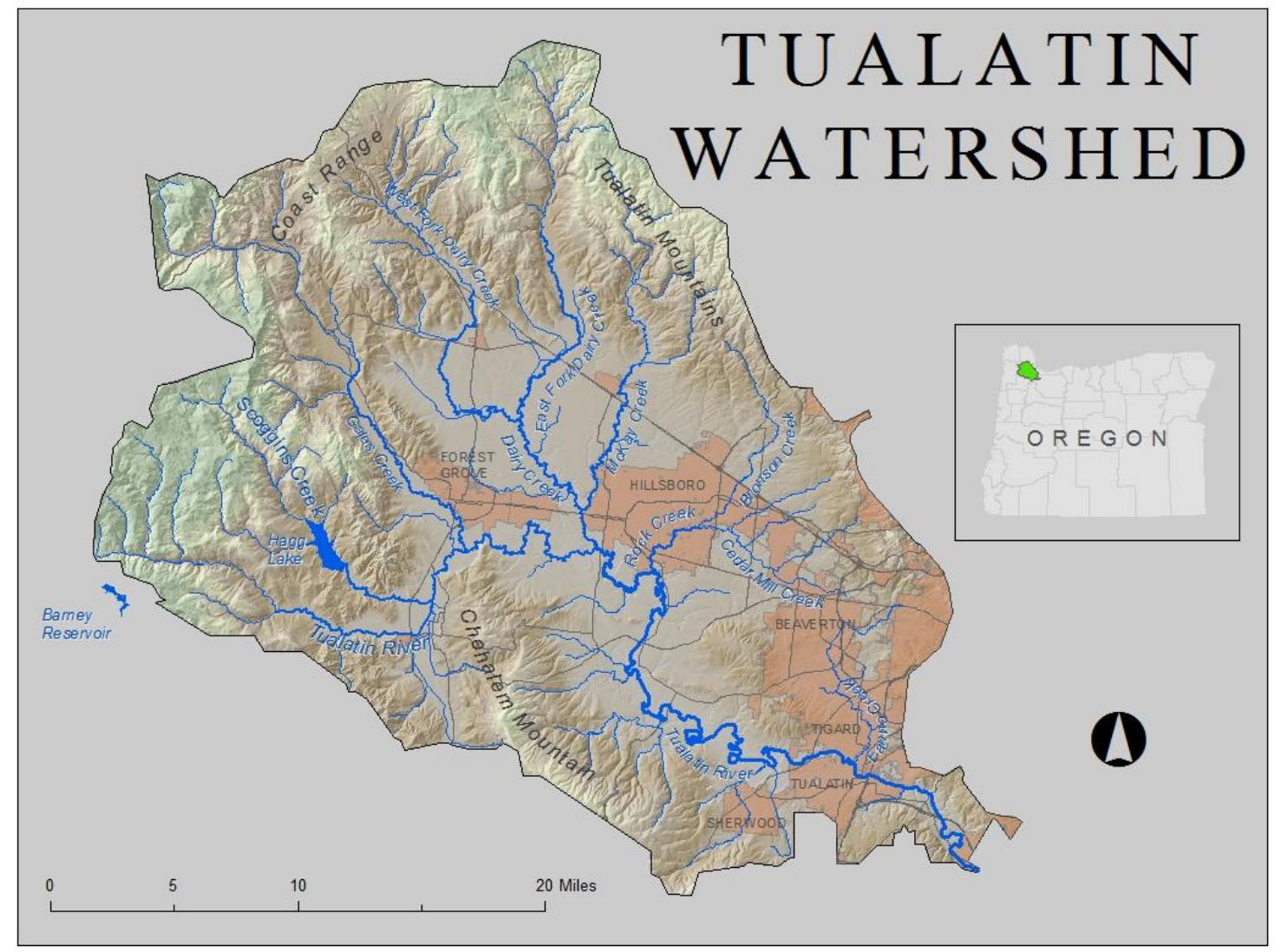

Figure 7: Tualatin Watershed (Data Sources: Metro 2012, USGS 2012)

The Tualatin River is about 83 miles long, with the headwaters located in the Coast Range west of Gaston. The river drops an average rate of 74 feet/mile to about River Mile (RM) 55.3, traversing a mostly forested landscape that characterizes land use in the uplands. From RM 55.3 to RM 33.3, the rate of descent decreases dramatically to an average rate of $1.3 \mathrm{feet} / \mathrm{mile}$ as it meanders through a generally agricultural landscape. The slope decreases again to a reservoirlike descent of less than 0.1 feet/mile between RM 33.3 and RM 3.4, where a low-head dam 
diverts water to Lake Oswego. This area contains both agricultural and urban land uses. Below the dam, the river is a free-flowing series of pools and riffles that descends at an average rate of 1.3 feet/mile to where it joins the Willamette River. River width varies from about 15 feet in the headwaters to nearly 150 feet above the diversion dam at RM 3.4 (Risley 1997) (figure 8).

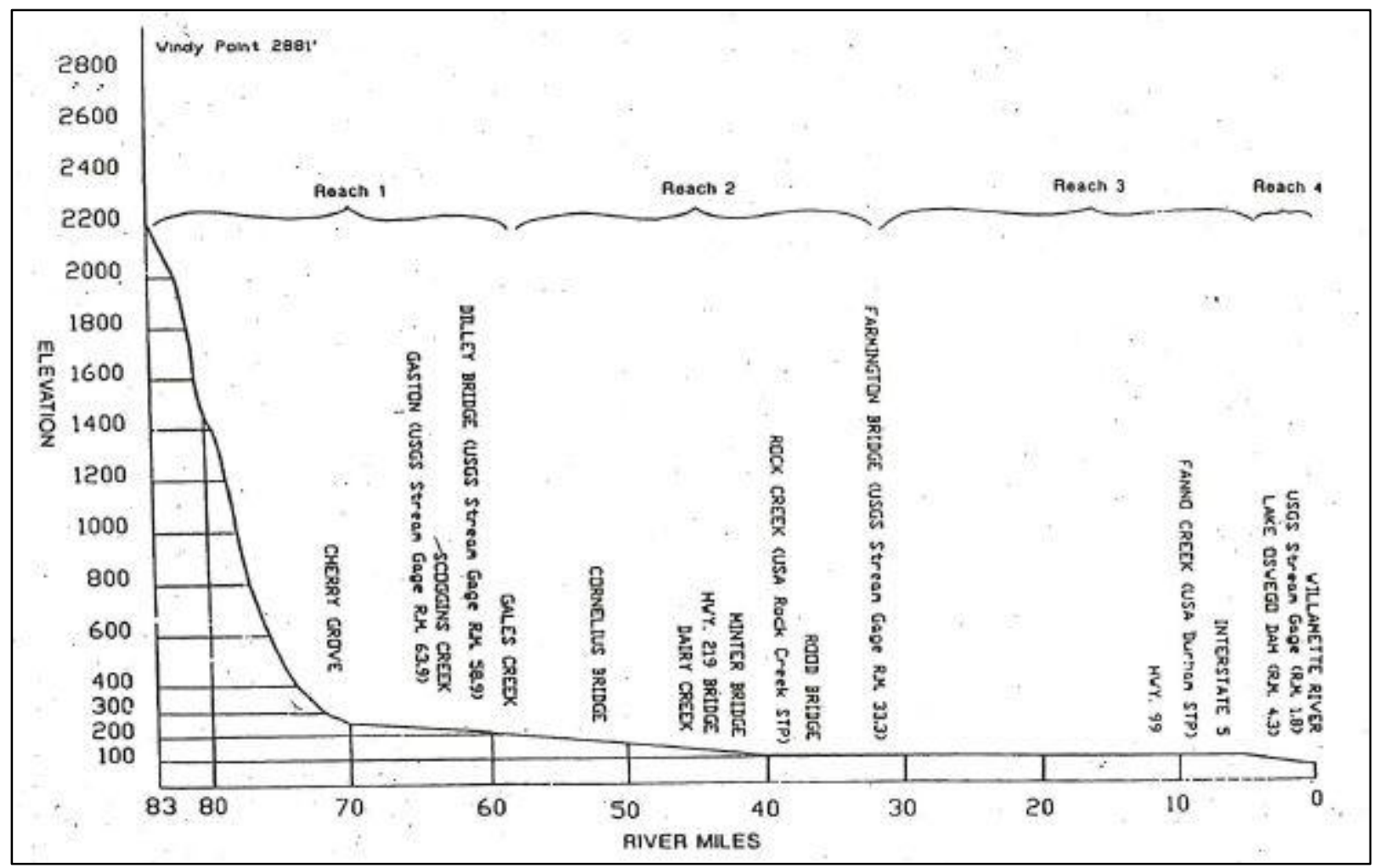

Figure 8: Tualatin River Elevation Profile (Source: TRWC 2001)

\section{Climate}

The basin has a marine west coast climate, characterized by mild wet winters and warm dry summers. Precipitation in the basin averages about 45 inches, with nearly $80 \%$ of that falling between October and March. Due to relatively low elevations and the moderating effects of the marine climate, most of the precipitation is rain. While snowfall is common in the higher 
elevations of the basin, the snowpack does not persist into summer (Chang 2007). Summer months are usually dry, with less than an inch of rainfall in July and August. Air temperatures average between 32 and $62.6^{\circ} \mathrm{F}$ in the winter and between 41 and $82.4^{\circ} \mathrm{F}$ in the summer (figure 9). Streamflow follows the precipitation pattern, with peak flows usually occurring between December and March, and low flows from July to October (Risley 1997).

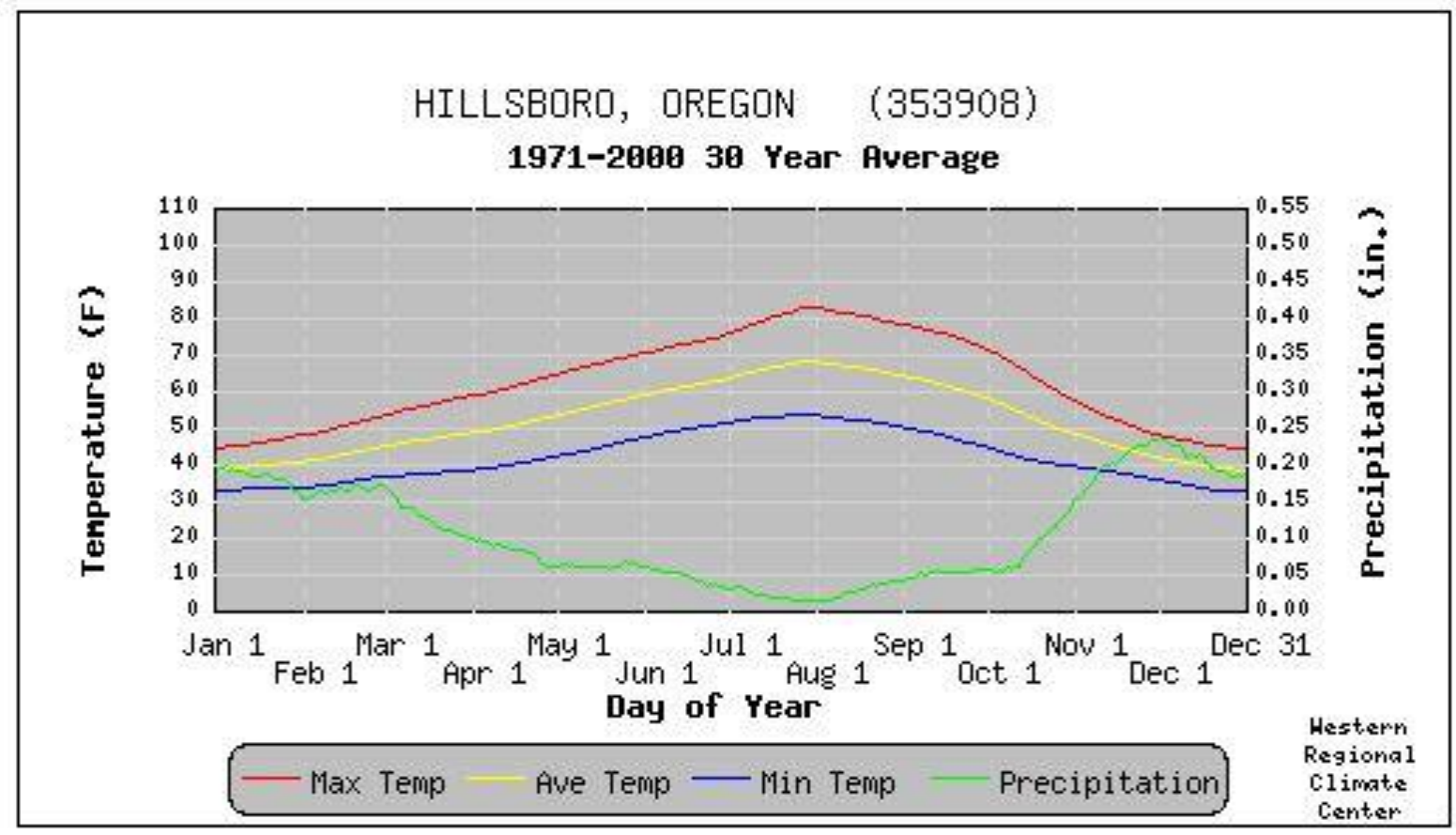

Figure 9: Hillsboro, OR Average Temperature and Rainfall (Source: Western Regional Climate Center 2014)

Prior to the construction of Scoggins Reservoir (Hagg Lake) in 1975, streamflow on the Tualatin was unregulated, and mean flow at West Linn in August was 16.8 cfs from 1955-1974, sometimes dropping to below $10 \mathrm{cfs}$. After dam construction, water from Hagg Lake was used to augment summer flow volume; August mean streamflow at West Linn was 142.4 cfs from 1974-1994 (Risley 1997) (figure 10). 


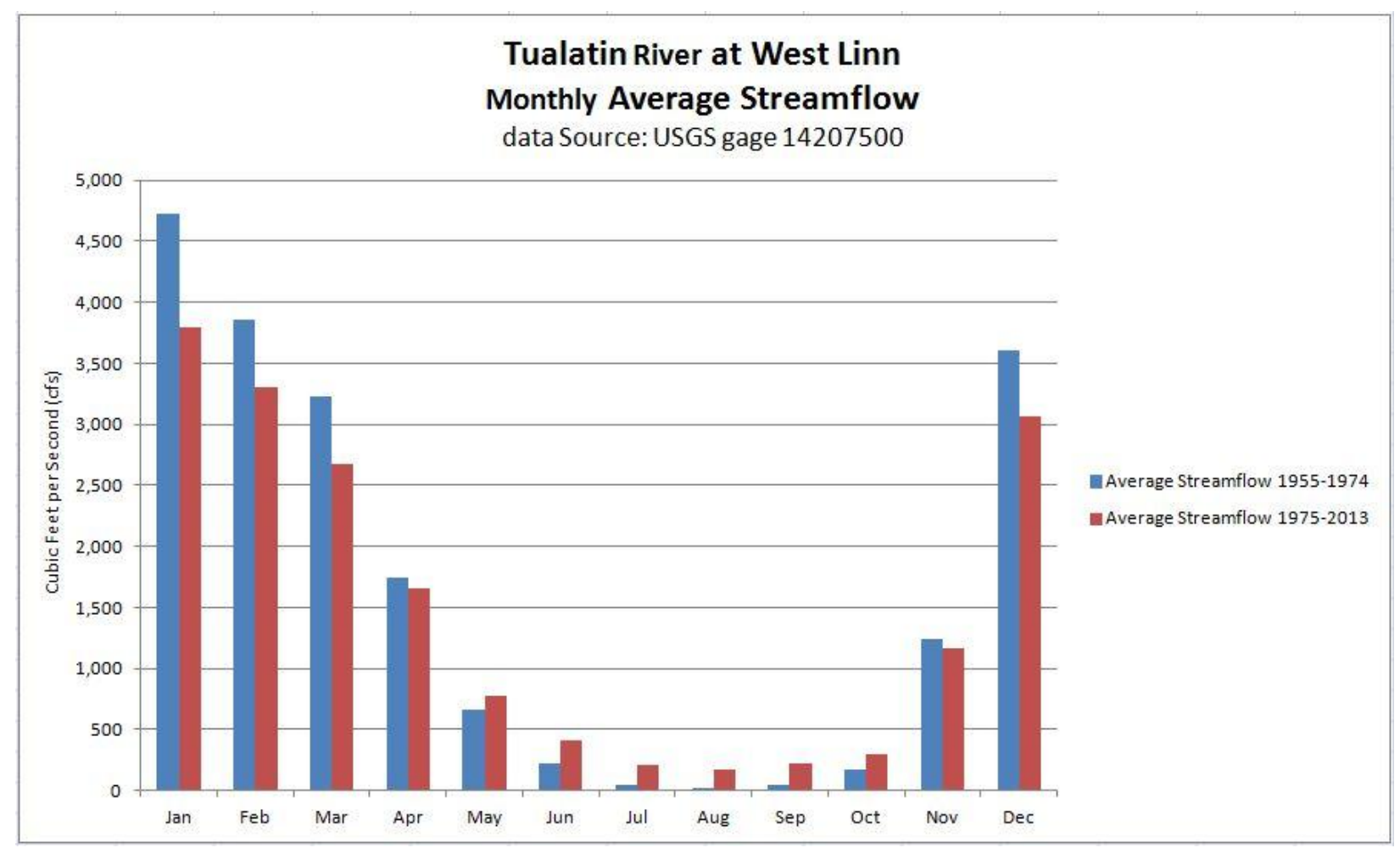

Figure 10: Tualatin River monthly average streamflow (Source: USGS 2014)

\section{Land Use}

Land use in the Tualatin basin is a mix of forested, agricultural and urban areas.

Forestlands occupy approximately $39 \%$ of the basin, mostly in upland areas. Agricultural and urban land use dominates the basin lowlands, occupying $35 \%$ and $26 \%$ of the basin, respectively (DEQ 2012) (figure 11). The 2010 population of Washington County, which contains most of the basin, was 529,710, and grew 4.8\% to 554,926 in 2013 (US Census Bureau 2014). 


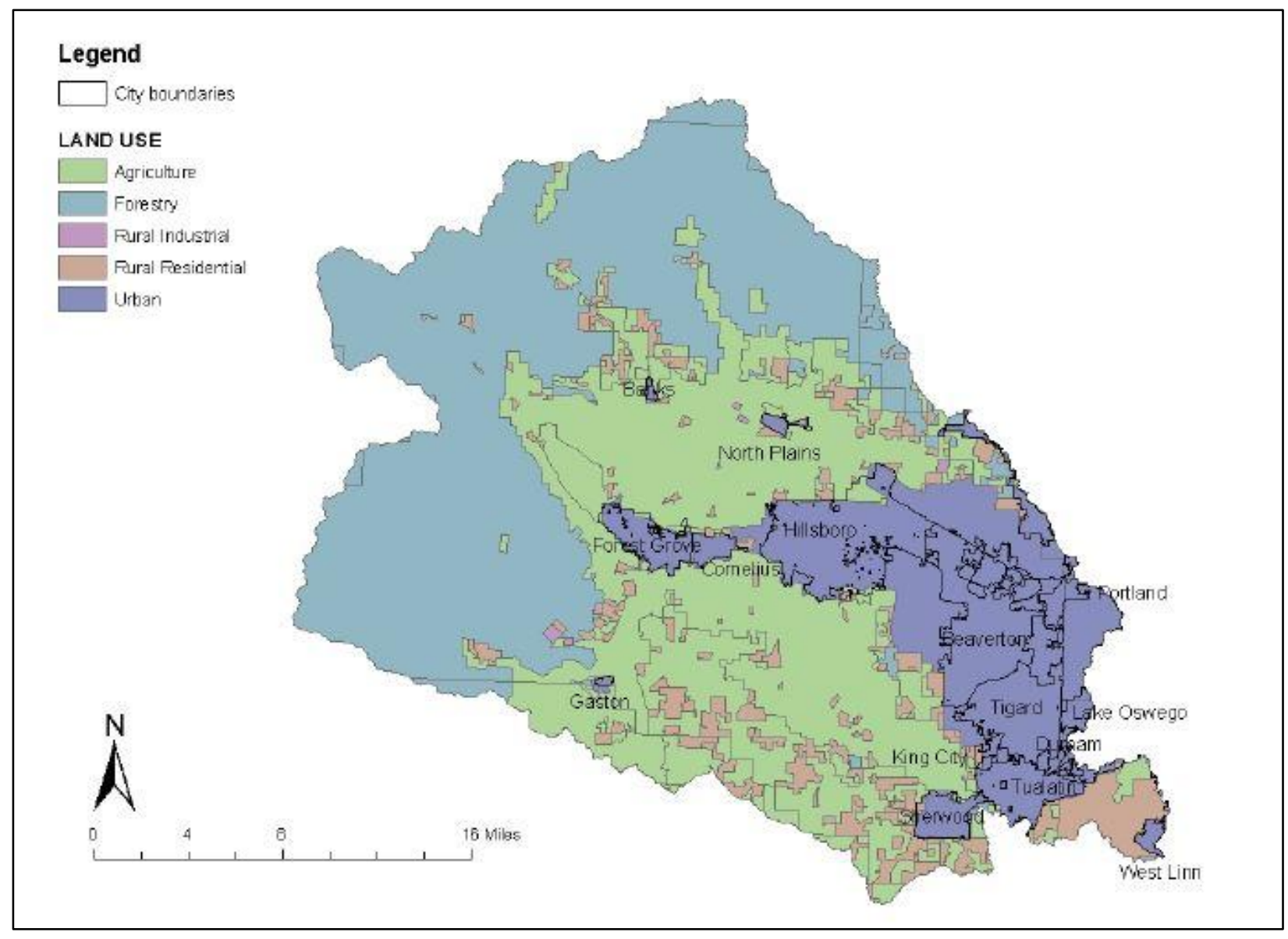

Figure 11: Tualatin basin land use (Source: DEQ 2012)

\section{Water management infrastructure}

Several major water management facilities affect streamflow and water temperature in the Tualatin basin (figure 12). The major stakeholders in these facilities include Clean Water Services, Tualatin Valley Irrigation District (TVID), Joint Water Commission (JWC), Tualatin Valley Water District (TVWD), Lake Oswego Corporation, and the cities of Hillsboro, Beaverton and Forest Grove (CWS 2012a). 
Barney Reservoir, located in the adjacent Trask River basin, augments the supply of water to the Tualatin basin via a 36 inch pipe that empties into the Tualatin River near RM 78 (Murdock 2004). The City of Hillsboro has a withdrawal point at RM 73.3 for municipal water; withdrawals are usually less than 2cfs. TVID has two release point near RM 64 that provide irrigation water to customers in the Patton Valley northwest of Gaston, using water supplied from a pump on Scoggins Creek below Hagg Lake. A pumping station at RM 62 is operated by the U.S. Fish and Wildlife Service (USFS) to provide water to the Wapato Lake Wildlife Refuge.

Hagg Lake releases water for flow augmentation, irrigation, and municipal and industrial use into the Tualatin River at RM 60 via Scoggins Creek. The Springhill pumping station at RM 56.1, jointly owned by TVID and JWC, distributes water for irrigation and for municipal and industrial use.

Just downstream at RM 55.2 is the Forest Grove WWTF, operated by CWS. This facility and the Hillsboro WWTF at RM 43.8 only discharge treated effluent during high flow periods; during the summer low flow season, the effluent is pumped to the Rock Creek WWTF at RM 38.1 for treatment and release. The last CWS facility on the Tualatin is the Durham WWTF at RM 9.3. The City of Lake Oswego diverts less than 5 cfs of water from the Tualatin River into the Lake Oswego Canal at RM 6.7 (CWS 2009); it also operates a low-head dam at RM 3.4 (CWS 2006). 


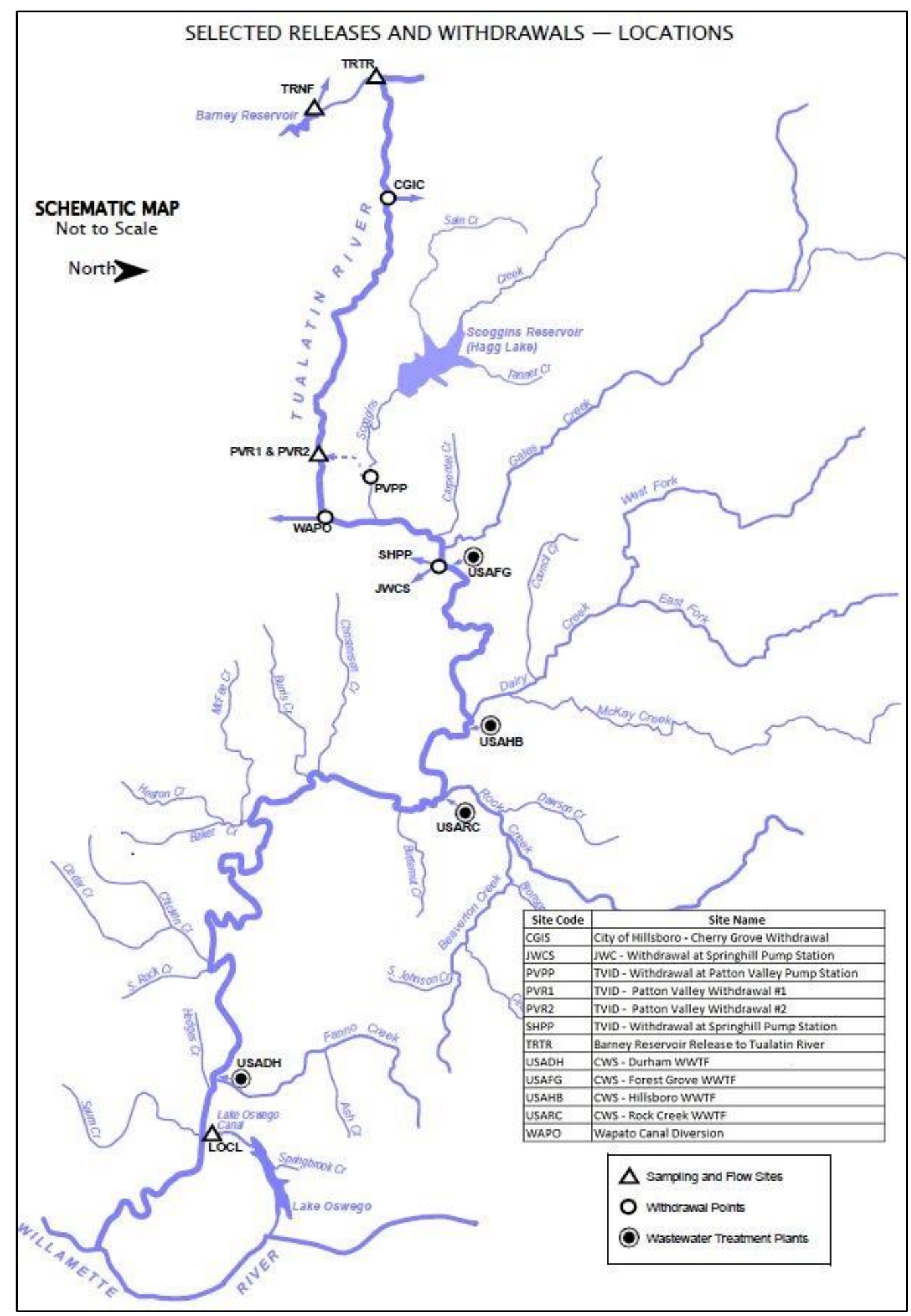

Figure 12: Tualatin River Water Management Infrastructure (Source: CWS 2006) 
Barney Reservoir has a capacity of 20,000 acre-feet, with 16,540 acre-feet available for diversion into the Tualatin basin. Water from this reservoir is allocated between JWC member agencies and CWS (table 2). Half of Scoggins Reservoir's 53,640 acre-feet capacity is allocated to TVID, while JWC, CWS and Lake Oswego Corporation share the remainder (CWS 2012a) (table 3).

Table 2: Barney Reservoir Water Allocation (Source: CWS 2012a)

\begin{tabular}{|c|c|c|c|}
\hline \multicolumn{4}{|c|}{ RESERVOIR OWNERSHIP AND WATER ALLOCATION FOR BARNEY RESERVOIR } \\
\hline & \multirow{2}{*}{$\begin{array}{l}\text { Reservoir } \\
\text { Ownership }\end{array}$} & \multicolumn{2}{|c|}{ Water Allocation } \\
\hline & & Acre-Feet & Percent \\
\hline Dead pool & $0.0 \%$ & 460 & $2.3 \%$ \\
\hline Oregon Department of Fish and Wildlife (ODFW) & $0.0 \%$ & 3000 & $15.0 \%$ \\
\hline \multicolumn{4}{|c|}{ Volume remaining to be divided among partners: 16,540 ac-ft } \\
\hline Tualatin Valley Water District (TVWD) & $35.0 \%$ & 5789 & $28.9 \%$ \\
\hline City of Hillsboro & $31.0 \%$ & 5127 & $25.6 \%$ \\
\hline City of Beaverton & $21.5 \%$ & 3556 & $17.8 \%$ \\
\hline Clean Water Services & $10.0 \%$ & 1654 & $8.3 \%$ \\
\hline City of Forest Grove & $2.5 \%$ & 414 & $2.1 \%$ \\
\hline TOTAL & $100.0 \%$ & 20,000 & $100.0 \%$ \\
\hline
\end{tabular}

Table 3: Scoggins Reservoir Water Allocation (Source: CWS 2012a)

\begin{tabular}{|lllc|}
\hline \multicolumn{2}{c}{ ALLOCATION OF WATER FROM SCOGGINS RESERVOIR } \\
\hline \multicolumn{1}{c}{ Contracted To } & \multicolumn{1}{c|}{ Water Use } & \multicolumn{2}{c|}{ Available Volume } \\
\cline { 2 - 4 } & & ac-ft & as percent \\
\hline Tualatin Valley Irrigation District & $\begin{array}{l}\text { Irrigation } \\
\text { (up to } 17,000 \text { acres) }\end{array}$ & 27,022 & $50 \%$ \\
Joint Water Commission & Municipal and & 13,500 & $25 \%$ \\
City of Beaverton & industrial & 4,000 & \\
City of Forest Grove & & 4,500 & \\
City of Hillsboro & & 5,000 & \\
Clean Water Services & Instream water & 12,618 & $24 \%$ \\
Lake Oswego Corporation & quality & 500 & $1 \%$ \\
\hline Total & Irrigation & $\mathbf{5 3 , 6 4 0}$ & $\mathbf{1 0 0 \%}$ \\
\hline
\end{tabular}


The Spring Hill pumping plant, jointly operated by TVID and JWC, is the largest withdrawal point in the Tualatin basin. JWC uses its withdrawal to supply water to 300,000 residents in Washington County (figure 13), and TVID supplies irrigation water to 17,000 acres of farmland through 120 miles of pipeline (figure 14). From June to October of 2012, JWC had daily withdrawals of $26.3 \mathrm{cfs}$ to $87.7 \mathrm{cfs}$; TVID daily withdrawals were between $4.7 \mathrm{cfs}$ and $80 \mathrm{cfs}$ (CWS 2012a).

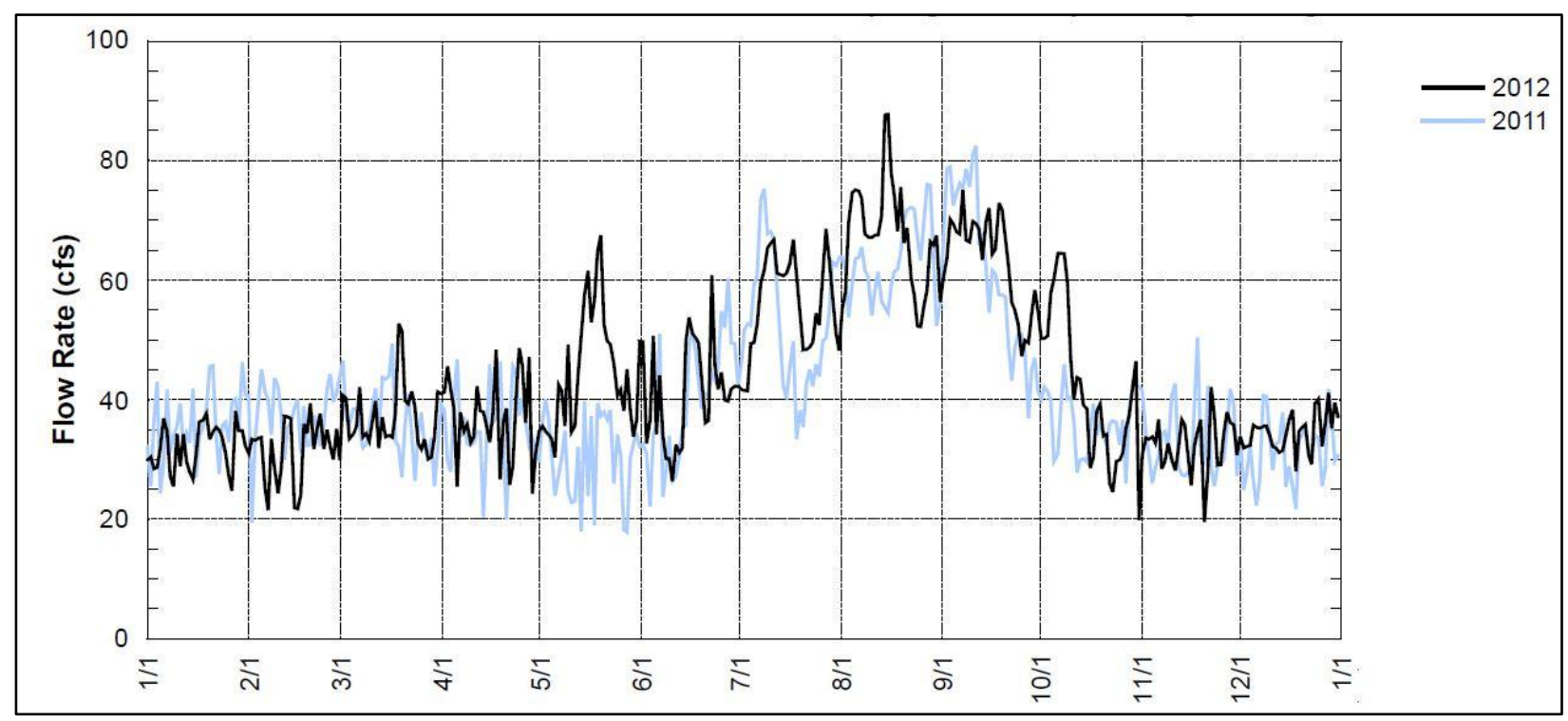

Figure 13: JWC Withdrawals at Spring Hill Pumping Plant (Source: CWS 2012a) 


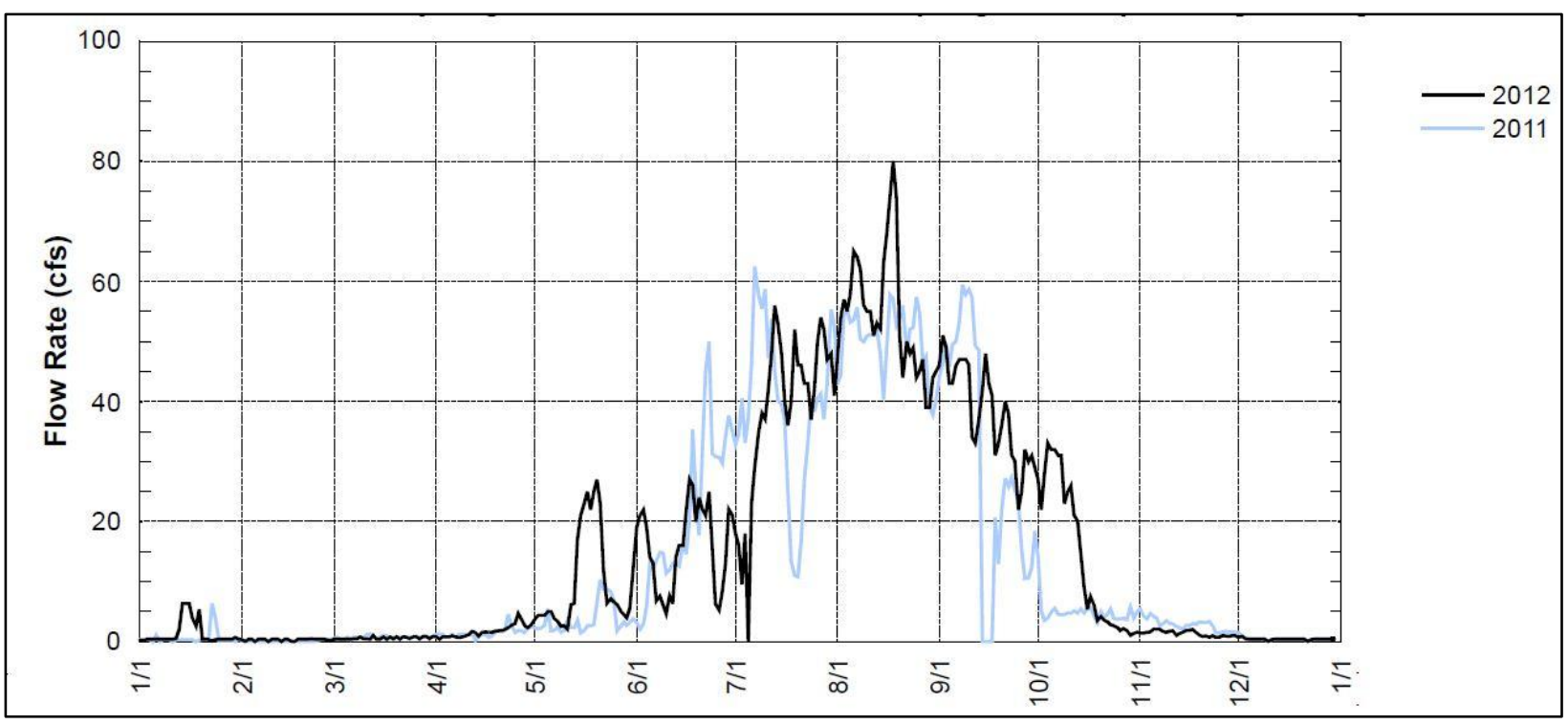

Figure 14: TVID Withdrawals at Spring Hill Pumping Plant (Source: CWS 2012a)

CWS operates four WWTFs, but only two (Rock Creek and Durham) discharge warmed effluent into the Tualatin River during summer months. Wastewater from the Forest Grove and Hillsboro facilities is piped to Rock Creek for processing during low flow periods. For July and August 2012, mean daily discharge from the Rock Creek WWTF ranged from 42.3 to 55.5 cfs, while Durham's average discharge was 24.8 cfs to 32.2 cfs (CWS 2012a). WWTF discharge is a significant contributor to Tualatin River streamflow during summer months.

\section{Water sources and use}

Sources of water to the basin include direct precipitation within the basin, water transferred from Portland Water Bureau sources for municipal and industrial use, and water piped into the Upper Tualatin River from Barney Reservoir. From May to October, water is consumed primarily by municipalities (45,000 to 50,000 acre-feet) and irrigators (30,000 to 
40,000 acre-feet); Clean Water Services uses its 14,600 acre-feet of stored water from July through October to maintain in-river flows between 120 to 180 cfs (CWS 2005a).

\section{Managing Stream Temperature in the Tualatin Basin}

This section describes the rules governing stream temperatures and the parties involved in temperature management, how stream temperature thresholds were established, and how a watershed-based water quality trading program is being used to manage temperatures in the Tualatin basin.

\section{Tualatin basin temperature Total Maximum Daily Loads}

The Clean Water Act (CWA) is the basis for water pollution regulation in the United States, and the U.S. Environmental Protection Agency (EPA) is the agency responsible for administration of the CWA. Each state creates its own legislation and administrative rules governing water pollution, compliant with the CWA. In Oregon, the Department of Environment Quality (DEQ) is the agency that oversees water quality issues (DEQ 2001).

The DEQ monitors water quality in the state to determine whether water quality standards are being met. For waters that are not compliant with standards, the DEQ then determines if the violation impairs a beneficial use. If a beneficial use is impaired, the DEQ must establish the criteria that will protect the beneficial use. Streams that exceed the criteria are designated as water quality limited, and the DEQ sets Total Maximum Daily Load (TMDL) criteria that specify how much of a pollutant can be added to the stream without harm to beneficial uses. The DEQ then works with Designated Management Agencies (DMAs) to create a Water Quality Management Plan (WQMP) for each watershed that lists the stream segments 
that are not in compliance with the water quality criteria, and the actions required to restore those segments to compliance (DEQ 2001). The DMAs for the urbanized portion of the Tualatin basin include Clean Water Services and county, city and regional governments within the basin. The DEQ has delegated the authority to manage pollution from agricultural activities to the Oregon Department of Agriculture (ODA) and to the Oregon Department of Forestry (ODF) for forestry activities on state and private lands (CWS 2005a, IMST 2004).

TMDL criteria are established to protect the beneficial use most sensitive to a pollutant. Because salmonids and other aquatic species are most sensitive to elevated stream temperatures, the temperature TMDL is based on their needs throughout their lifecycles (IMST 2004). The DEQ's 2012 303(d) list for temperature shows 198.4 miles of stream segments in the Tualatin basin that do not meet water quality standards for temperature (DEQ 2014a) (table 4 and figure $15)$.

Table 4: Tualatin basin 303(d) listed streams (Compiled from data in DEQ 2014a)

\begin{tabular}{|c|c|c|c|c|c|c|c|c|}
\hline \multicolumn{3}{|c|}{ TMDL Approved } & \multicolumn{3}{|c|}{ Insufficient Data } & \multicolumn{3}{|c|}{ Attaining } \\
\hline Water Body & River Miles & Length & Water Body & River Miles & Length & Water Body & River Miles $\mathrm{L}$ & Length \\
\hline Ash Creek & 0 to 3.7 & \begin{tabular}{|l|}
3.7 \\
\end{tabular} & Burris Creek & 0 to 6 & 6 & Gales Creek & 11 to 27.7 & 16.7 \\
\hline Beaverton Creek & 0 to 9.8 & 9.8 & Carpenter Creek & 0 to 6.3 & 6.3 & McKay Creek & 15.8 to 22.7 & 6.9 \\
\hline Bronson Creek & 0 to 6.5 & 6.5 & Cedar Creek & 0 to 6.8 & 6.8 & Scoggins Creek & 0 to 5.1 & 5.1 \\
\hline Butternut Creek & 0 to 5.3 & 5.3 & Chicken Creek & 0 to 7 & 7 & Tualatin River & 44.7 to 69.9 & 25.2 \\
\hline Cedar Creek & 0 to 6.8 & 6.8 & Christensen Creek & 0 to 6.4 & 6.4 & Tualatin River & 69.9 to 80.7 & 10.8 \\
\hline Dairy Creek & 0 to 10.1 & 10.1 & Heaton Creek & 0 to 5.2 & 5.2 & & & \\
\hline East Fork Dairy Creek & 0 to 13.5 & 13.5 & McFee Creek & 0 to 8.3 & 8.3 & Total & & 64.7 \\
\hline Fanno Creek & 0 to 13.9 & 13.9 & Wapato Creek & 0 to 6.7 & 6.7 & & & \\
\hline Gales Creek & 0 to 11 & 11 & & & & & & \\
\hline Hedges Creek & 0 to 0 & 0 & Total & & 52.7 & & & \\
\hline Johnson Creek & 0 to 3.7 & 3.7 & & & & & & \\
\hline Johnson Creek & 0 to 4 & 4 & & & & & & \\
\hline McKay Creek & 0 to 15.8 & 15.8 & & & & & & \\
\hline Rock Creek & 0 to 18.2 & 18.2 & & & & & & \\
\hline Summer Creek & 0 to 4 & 4 & & & & & & \\
\hline Tualatin River & 0 to 44.7 & 44.7 & & & & & & \\
\hline Unnamed (Nyberg Creek) & 0 to 1.3 & 1.3 & & & & & & \\
\hline West Fork Dairy Creek & 0 to 23.7 & 23.7 & & & & & & \\
\hline Williams Canyon & 0 to 2.4 & 2.4 & & & & & & \\
\hline Total & & 198.4 & & & & & & \\
\hline
\end{tabular}




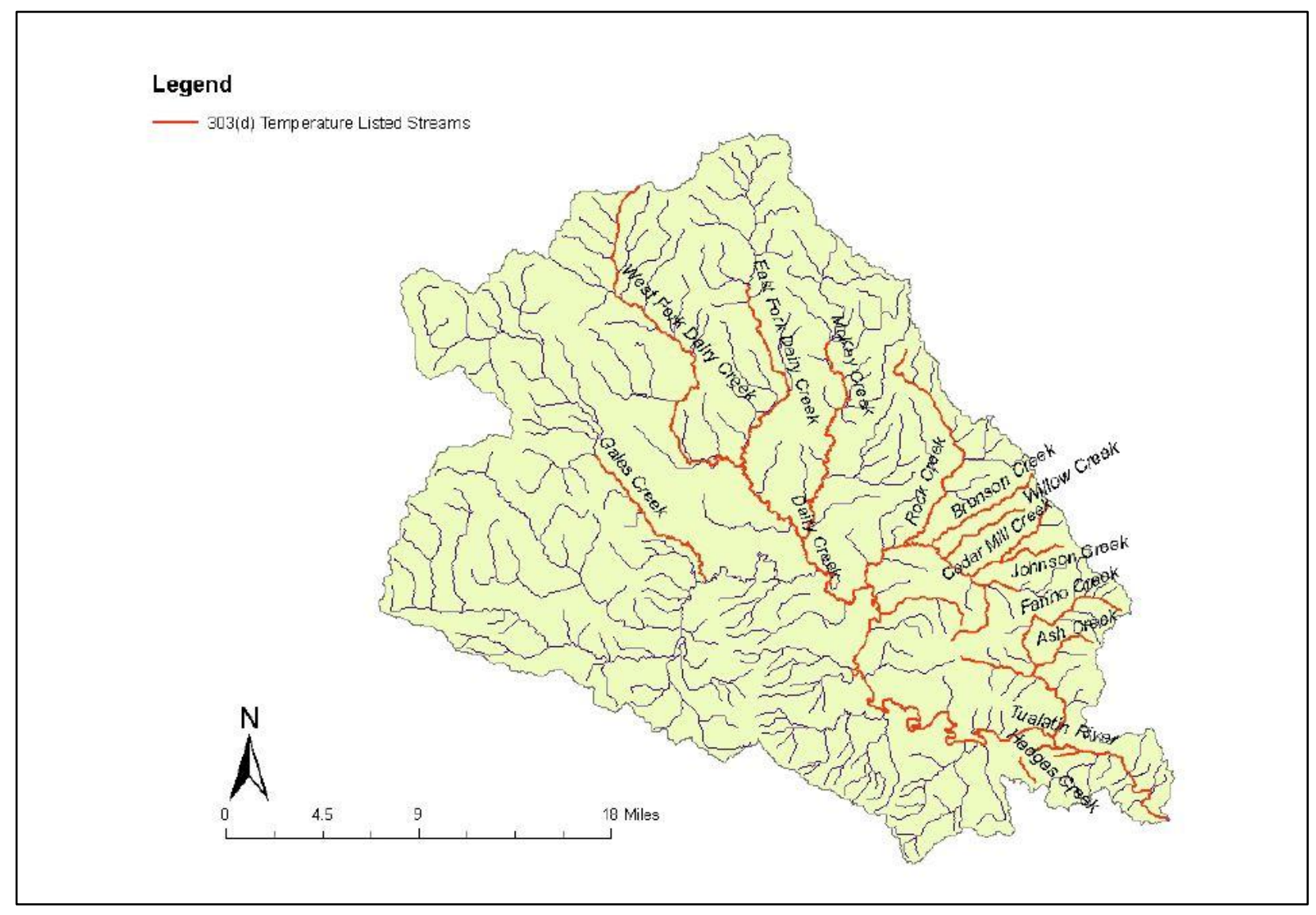

Figure 15: 303(d) temperature listed streams (Source: DEQ 2011)

\section{Stream temperature criteria for the Tualatin basin}

The Tualatin basin contains two resident salmonid species: Cutthroat trout

(Oncorhynchus clarki) and Rainbow trout (O.mykiss). Two anadromous salmonids are also

present; coho salmon (O. kisutch) and winter steelhead (O.mykiss). Temperature criteria assigned to Tualatin basin streams vary depending on salmonid lifecycle needs (DEQ 2001) (Figure 16). Streams that support salmon and trout rearing and migration (figure 17) should not exceed $64.4^{\circ}$ F. Streams identified as spawning habitat (figure 18) should be less than $55.4^{\circ} \mathrm{F}$ during spawning seasons: January 1 to May 15 for steelhead and October 15 to May 15 for coho and cutthroat. 


\begin{tabular}{|c|c|c|c|c|c|c|c|c|c|}
\hline $\begin{array}{l}\text { Species and } \\
\text { Life Stages }\end{array}$ & Oct. & Nov. & Dec. & Jan. & Feb. & March & April & May & June \\
\hline $\begin{array}{l}\text { Winter } \\
\text { Steelhead }\end{array}$ & & & & & & & & & \\
\hline $\begin{array}{l}\text { Spawning, } \\
\text { incubation and } \\
\text { fry emergence* }\end{array}$ & & & & & & & & & \\
\hline Coho & & & & & & & & & \\
\hline $\begin{array}{l}\text { Spawning, } \\
\text { incubation and } \\
\text { fry emergence* }\end{array}$ & & & & & & & & & \\
\hline Cutthroat & & & & & & & & & \\
\hline $\begin{array}{l}\text { Spawning, } \\
\text { incubation and } \\
\text { fry emergence }\end{array}$ & & & & & & & & & \\
\hline
\end{tabular}

Figure 16: Tualatin basin salmonid life cycle (Source: DEQ 2001)

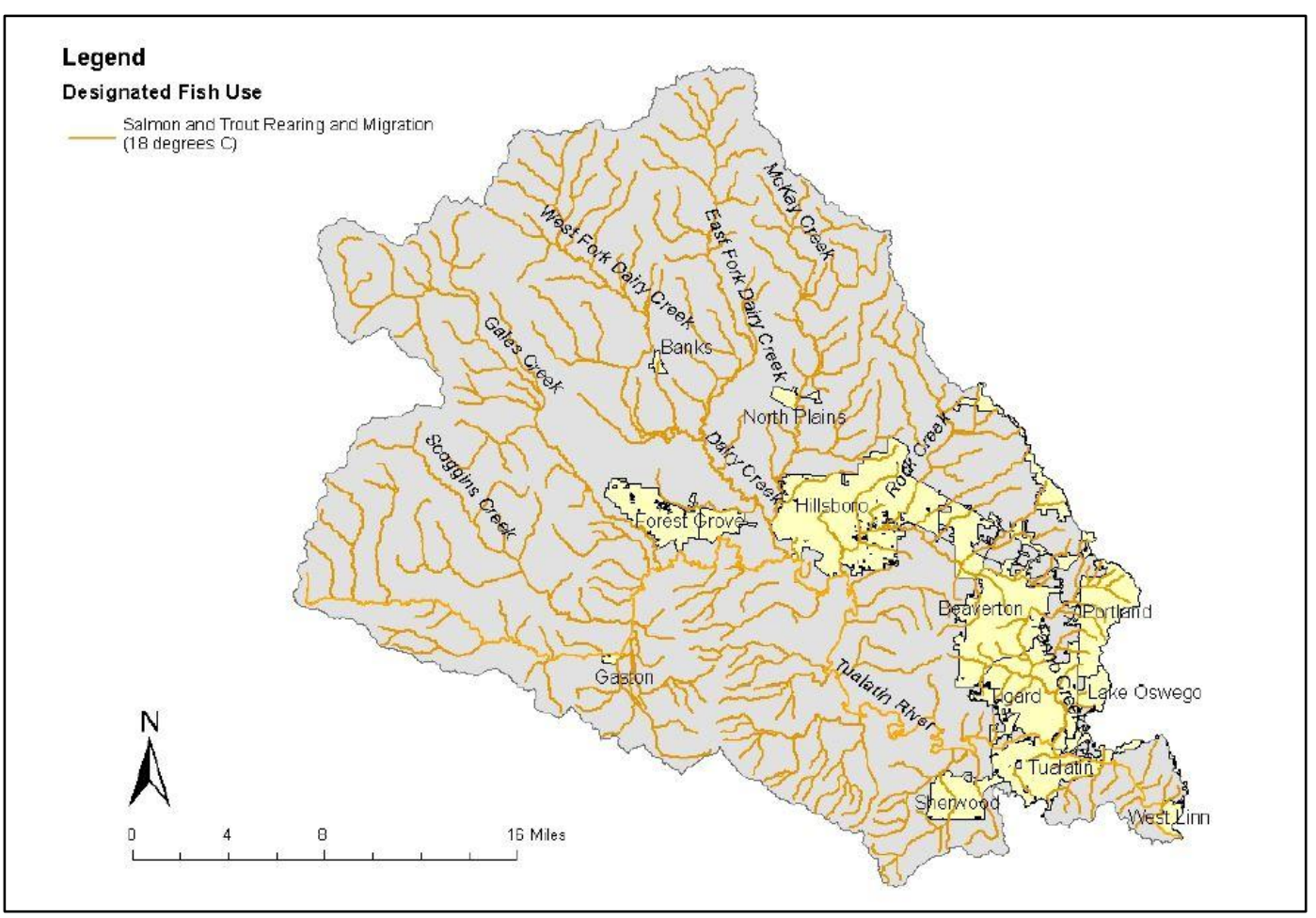

Figure 17: Tualatin basin designated fish use streams (Source: DEQ 2001) 


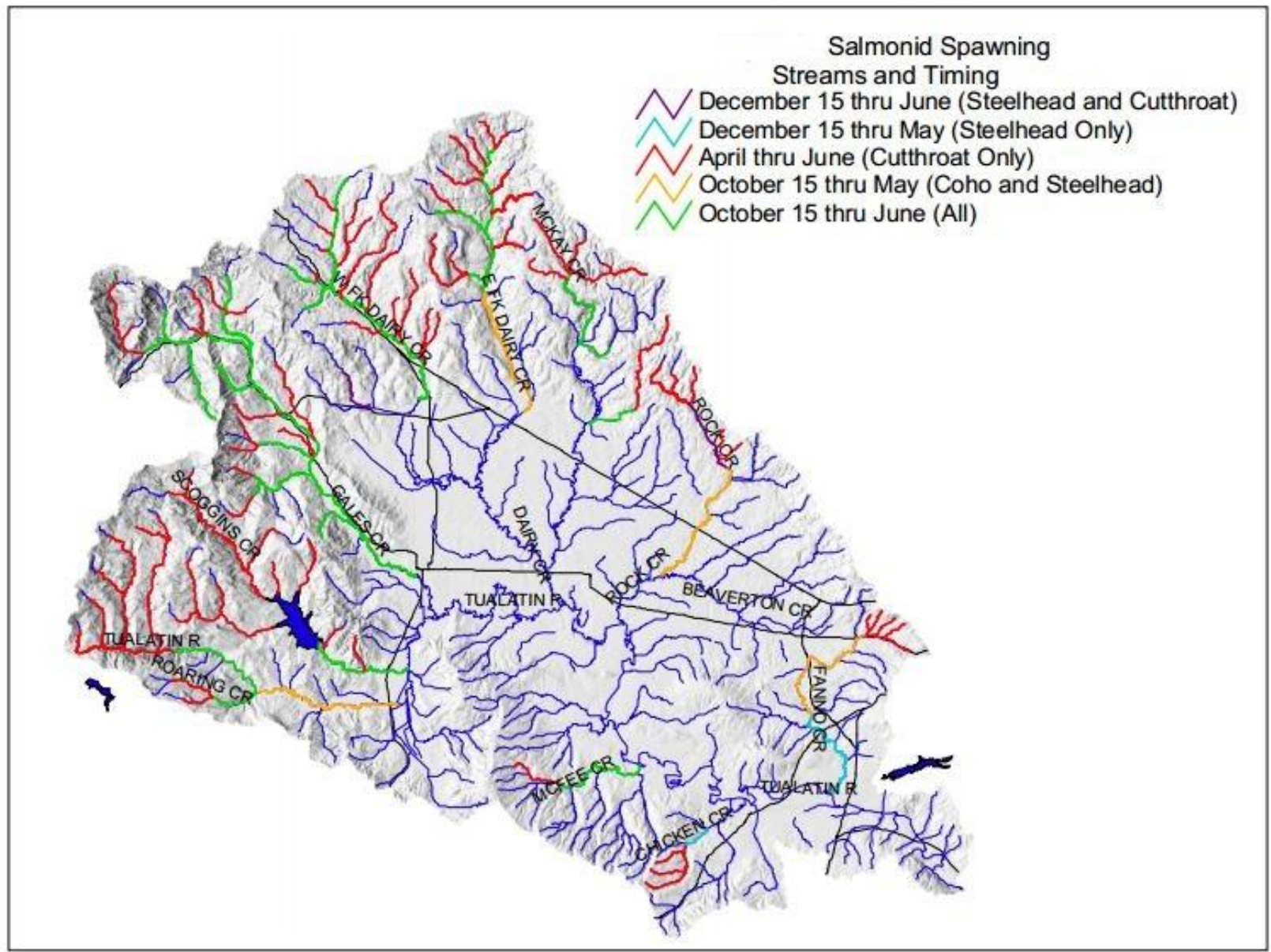

Figure 18: Tualatin basin designated salmon and steelhead spawning use streams (Source: DEQ 2001)

\section{Clean Water Services water quality trading program}

The Tualatin basin temperature TMDL limits point source stream temperature increases to $0.25^{\circ} \mathrm{F}$ greater than the temperature of the receiving stream. Both the Durham and Rock Creek WWTFs exceed these criteria during summer months (DEQ 2001). To meet the temperature standard, these facilities would need to reduce the heat load being added to the river by $95 \%$ (Cochran and Louge 2011). CWS explored several options to directly reduce effluent temperatures, but found them prohibitively expensive. Instead, CWS sought a watershed-based 
approach that offsets WWTF thermal load additions elsewhere in the basin rather than reducing it at the source (CWS 2005a). In 2005, the DEQ granted CWS Oregon's first integrated watershed-based NPDES permit, which was the first in the United States to allow temperature water quality trading (Cochran and Logue 2011). Under the terms of this permit, CWS can offset the WWTF thermal load by increasing streamflow and reducing solar radiation reaching streams in the watershed. Streamflow is increased by summer releases of water stored in reservoirs, and solar radiation is reduced by a riparian planting program that shades Tualatin River tributary streams. This program reduces costs for temperature mitigation and improves aquatic and terrestrial habitat in the watershed (Roll et al. 2010).

\section{Flow augmentation}

Flow-augmentation water releases generally occur from July through October each year, with the exact timing of releases dependent upon Tualatin River streamflow response to weather conditions. In 2012, CWS began releasing its allocation from Hagg Lake starting on July 7 and ending on October 29. Releases from Barney Reservoir started on August 31 and ended on

October 29 (table 5). Flow augmentation and WWTF releases are a major component of summer streamflow on the Tualatin River, usually exceeding natural flow during summer months (CWS 2012a) (figure 19). 
Table 5: 2012 Reservoir release summary (Source: CWS 2012a)

\begin{tabular}{|c|c|c|c|c|c|c|c|c|c|}
\hline \multicolumn{10}{|c|}{ CLEAN WATER SERVICES WATER RELEASE SUMMARY 2012} \\
\hline & Units & May & June & July & Aug & Sept & Oct & $\begin{array}{l}\text { Nov } \\
1-18\end{array}$ & Total \\
\hline \multirow[t]{2}{*}{ Scoggins Release } & acre-ft & 0 & 0 & 1,667 & 3,472 & 3,918 & 1,893 & 0 & 10,950 \\
\hline & days & 0 & 0 & 25 & 31 & 30 & 20 & 0 & 106 \\
\hline \multirow[t]{2}{*}{ Barney Release } & acre-ft & 0 & 0 & 0 & 28 & 833 & 806 & 0 & 1,667 \\
\hline & days & 0 & 0 & 0 & 1 & 30 & 29 & 0 & 60 \\
\hline Total Release & acre-ft & 0 & 0 & 1,667 & 3,500 & 4,752 & 2,698 & 0 & 12,616 \\
\hline $\begin{array}{l}\text { Daily Average Release } \\
\text { (for days with releases) }\end{array}$ & cfs & 0 & 0 & 34 & 57 & 80 & 47 & 0 & 55 \\
\hline \multicolumn{10}{|c|}{ Measured Flows for Tualatin River at Farmington (RM 33.3) - based on daily average } \\
\hline Measured minimum & cfs & 458 & 289 & 204 & 178 & 189 & 178 & 1,370 & - \\
\hline Measured mean & cfs & 945 & 444 & 250 & 205 & 205 & 395 & 1,538 & - \\
\hline Measured maximum & cfs & 1,890 & 795 & 387 & 237 & 225 & 1,430 & 1,660 & - \\
\hline
\end{tabular}

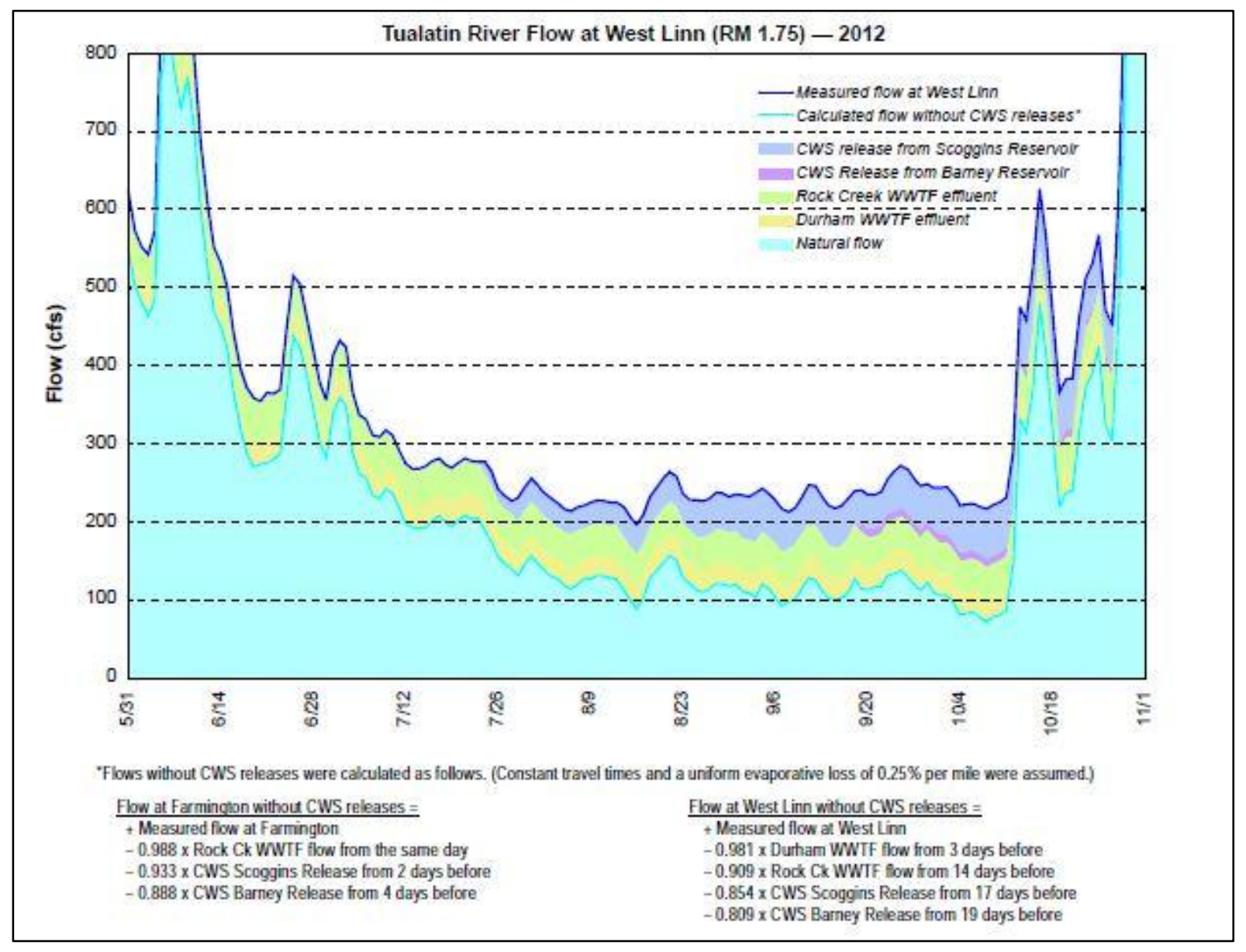

Figure 19: Tualatin river flow components at West Linn gage (Source: CWS 2012a) 
While most flow augmentation activity directly affects the Tualatin River, CWS has also partnered with TVID on several tributary flow restoration projects, using TVID's water distribution system to add water that increases streamflow in the Dairy Creek and Gales Creek subbasins (CWS 2012a) (figure 20).

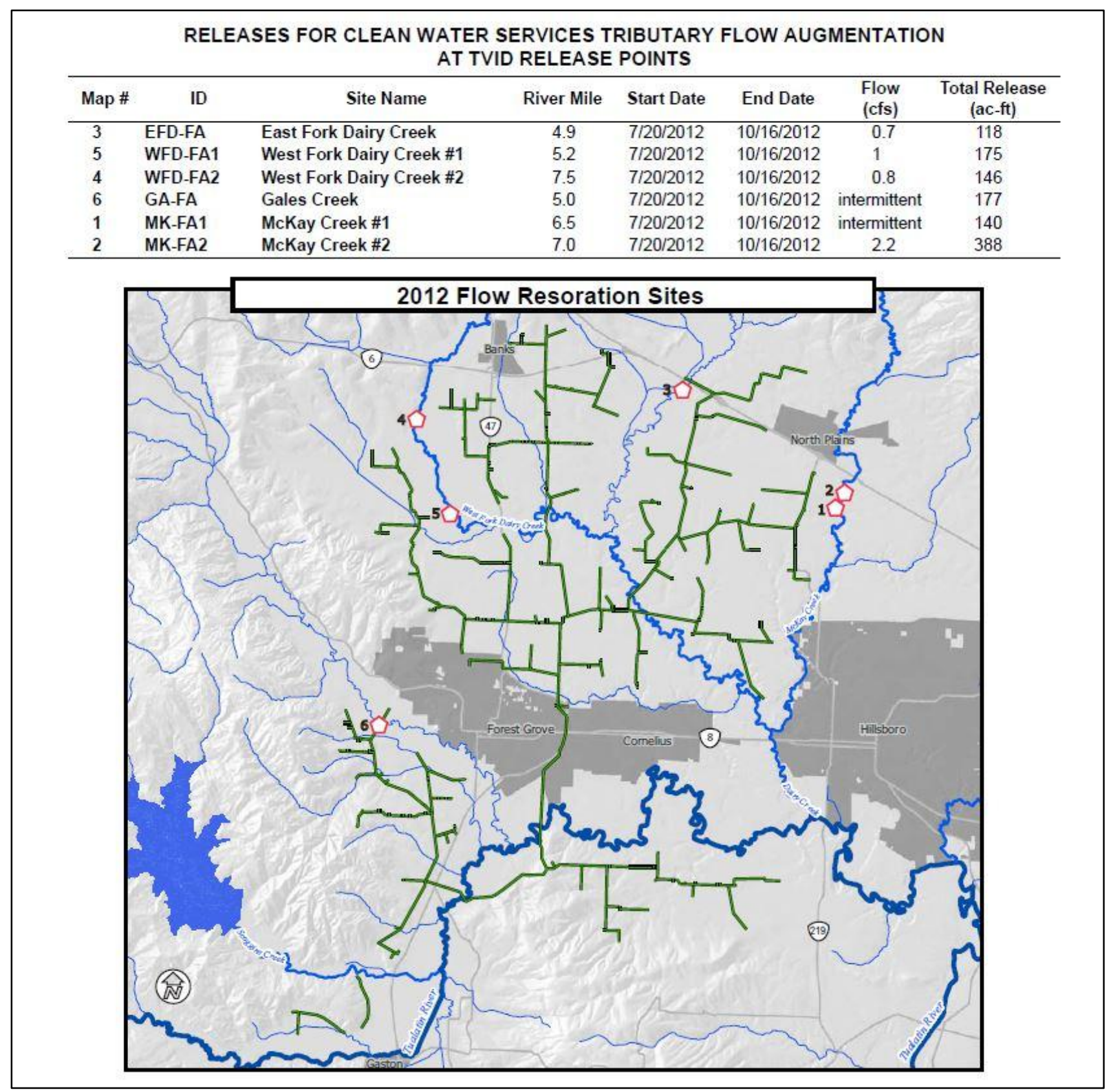

Figure 20: Tributary flow augmentation (Source: CWS 2012a) 


\section{Stream shading}

The 2005 CWS Temperature Management Plan included a five-year schedule of riparian planting to offset that portion of the WWTF thermal load that could not be managed by flow augmentation alone (CWS 2005a). During the initial permit period (2004-2008), around 35 miles of streamside plantings were completed, and CWS received a thermal credit of 295 million kcalories/day for shading (fig. 21).

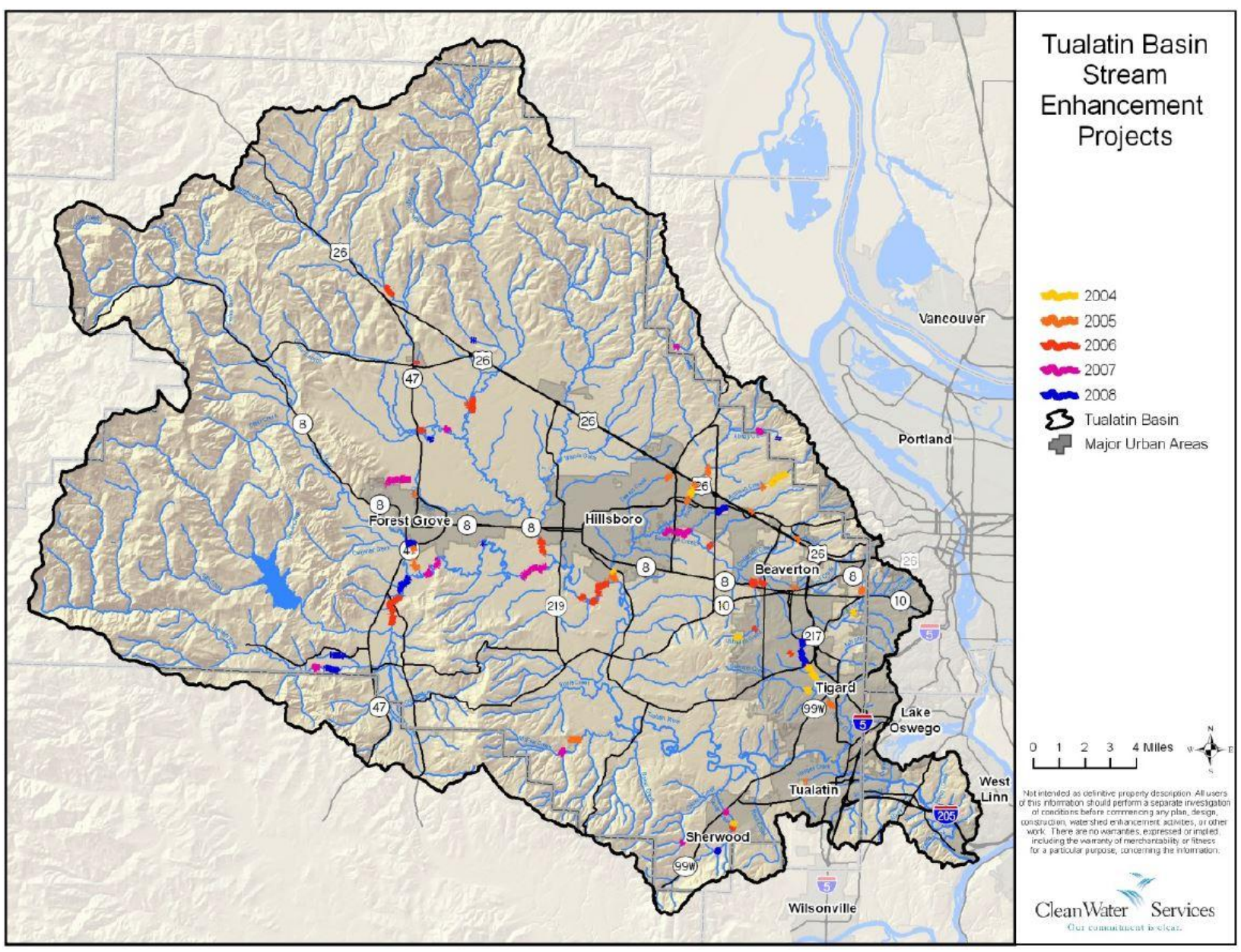

Figure 21: CWS 2004-2008 shade planting projects (source: CWS 2009)

The combined thermal credits for shade and flow augmentation offset the thermal load added by WWTF effluent discharged at Durham and Rock Creek. CWS planted an additional 13 
miles of riparian zones from 2009 to 2013 for an additional 84 million kcalories/day in thermal credits. Since CWS has met its current WWTF thermal load offset requirements, these excess credits are being held ("banked") to offset future discharge increases (CWS 2013) (table 6).

Table 6: CWS 2009-2013 shade planting banked thermal credits (Source: CWS 2013)

\begin{tabular}{|c|c|c|c|c|}
\hline \multirow{2}{*}{$\begin{array}{c}\text { Permit } \\
\text { Year }\end{array}$} & \multirow{2}{*}{\multicolumn{2}{|c|}{$\begin{array}{c}\text { Stream Miles Planted } \\
\text { Annual Cumulative }\end{array}$}} & \multicolumn{2}{|c|}{ Thermal Credits } \\
\hline & & & Annual & Cumulative \\
\hline$\overline{\text { Year } 6(2009)}$ & 3.5 & 3.5 & 12 million kcald & 12 million kcalvd \\
\hline Year 7 (2010) & 2.8 & 6.3 & 22 million kcalvd & 34 million kcaldd \\
\hline Year 8 (2011) & 1.5 & 7.8 & 20 milion kcalvd & 54 million kcald \\
\hline Year 9 (2012) & 2.1 & 9.9 & 8 million kcalvd & 62 million kcal/d \\
\hline Year $10(2013)$ & 3.1 & 13.0 & 21 milion kcalld & 84 million kcaldd \\
\hline
\end{tabular}

CWS utilizes the Community Tree-For-All program and Capital Improvement Program (CIP) for riparian planting projects in urban areas. Rural planting is done in cooperation with the Tualatin Soil and Water Conservation District (SWCD) using the Enhanced Conservation Reserve Enhancement Program (ECREP) program.

The Community Tree-For-All program partners with government agencies and volunteer community groups to plant vegetation along urban streams; CWS provides plants and technical support (Roll et al. 2010). Between 2005 and 2010, over 500,000 trees were planted as part of this program (table 7). The original goal of the Tree-For-All programs was to plant one million trees and shrubs by 2025 (2005 HSP), but this has since been expanded to four million riparian trees and shrubs, including one million between September 2014 and June 2015 (Tree For All 2014). 


\begin{tabular}{|c|c|c|c|c|c|c|c|c|c|c|}
\hline \multirow{2}{*}{$\begin{array}{l}\text { GlanWalu Sariucs } \\
\text { Trees \& Shrubs Planted } \\
\text { Jurisdiction }\end{array}$} & \multicolumn{7}{|c|}{$\begin{array}{l}\text { Tree Planting Challenge } \\
\qquad 2005-2010\end{array}$} & \multirow[b]{2}{*}{$\begin{array}{l}6 \text { Year } \\
\text { Challenge Goal }\end{array}$} & \multirow[b]{2}{*}{$\begin{array}{c}\text { Cumulative } \\
\text { Balance }\end{array}$} & \multirow{2}{*}{ \% Complete } \\
\hline & $\begin{array}{l}\text { Year } \\
\quad 2005\end{array}$ & 2006 & 2007 & 2008 & 2009 & 2010 & Grand Total & & & \\
\hline BANKS - Banks & 145 & 735 & 1,052 & 200 & 714 & & 2,846 & 2,253 & 593 & $128 \%$ \\
\hline BVRT - Beaverton & 8.801 & 22,842 & 18.057 & 32,856 & 29,548 & 18,173 & 128,277 & 124,442 & 3,835 & $103 \%$ \\
\hline CORN - Cornelius & 1.018 & 2,033 & 4,836 & 1,295 & 3.202 & 4,180 & 16,564 & 15,942 & 622 & $104 \%$ \\
\hline DUR - Durham & 105 & 650 & 200 & 964 & 527 & 300 & 2,746 & 2,205 & 541 & $125 \%$ \\
\hline FG - Forest Grove & 5.155 & 6,916 & 1,680 & 1.638 & 6.445 & 14,875 & 36,709 & 30,131 & 6,578 & $122 \%$ \\
\hline HILL - Hillsboro & 6,759 & 14,055 & 15,590 & 36.091 & 30,818 & 41,031 & 144,344 & 124,962 & 19,382 & $110 \%$ \\
\hline KC - King City & 158 & 400 & 375 & 1.480 & 610 & 400 & 3,403 & 3,309 & 94 & $103 \%$ \\
\hline NP - North Plains & 178 & 250 & 445 & 680 & 459 & 300 & 2,310 & 2,583 & $(273)$ & $89 \%$ \\
\hline SHER - Sherwood & 760 & 3.248 & 2,435 & 4.291 & 5,260 & 6,105 & 22,099 & 22,130 & (31) & $100 \%$ \\
\hline TIG - Tigard & 3,855 & 24,185 & 8.004 & 6,928 & 16.271 & 23,525 & 82,768 & 71,081 & 11,687 & $118 \%$ \\
\hline TUA - Tualatin & 1,493 & 4,467 & 8,878 & 8,747 & 9,858 & 13,611 & 47,054 & 39,045 & 8,009 & $121 \%$ \\
\hline WASHCO - Washington County & 2,168 & 4,148 & 1,302 & 3,375 & 9.605 & 9,325 & 29,823 & 21,258 & 8,665 & $141 \%$ \\
\hline Grand Total & 28,593 & 83,929 & 62,854 & 98,525 & 113,317 & 131,825 & 519,043 & 459,341 & 59,702 & $113 \%$ \\
\hline
\end{tabular}

The CIP aims to coordinate the capital projects and plans of the agencies and governments in the basin to protect ecological integrity and maintain compliance with regional and state regulations. The focus of the CIP is the implementation of infrastructure and conveyance projects. While not solely focused on riparian vegetation, more than 40 projects were completed 2004-2008 under the CIP program, resulting in more than 15 miles of streamside planting (Roll et al. 2010).

The two major vehicles for rural shade planting are the Vegetated Buffer Areas for Conservation and Commerce (VEGBAC) program and ECREP. Both provide financial benefits to rural landowners who lease land for riparian plantings, and provides additional benefits for landowners who grant conservation easements or transfer water rights. The original CREP program had generated little interest from rural landowners, primarily because the compensation offered was often less than the agricultural value of land. CWS worked with the Tualatin SWCD to develop ECREP, which provides additional flexibility and increased lease payments to landowners. Under ECREP, the Tualatin SWCD is responsible for managing planting and 
maintenance activities; CWS pays $63 \%$ of program costs, with the Farm Service Agency and other related organizations paying the remaining 37\% (Roll et al. 2010).

\section{Measuring shade planting effectiveness}

Under the terms of the 2005 NPDES permit, CWS is required to monitor shade planting sites to ensure that shade level targets are met (CWS 2005a). CWS measures canopy cover at each project site in the fifth year after planting, with monitoring points set at 500' intervals within the project boundary and a minimum of three points per project. The monitoring protocol includes upstream and downstream photos and densiometer readings at each point. Canopy coverage depends on a number of site-specific parameters, including riparian conditions before planting, competition from invasive plant species, and disturbance from riparian wildlife. Figure 22 shows the results of 2011 shade monitoring at the 2006 planting sites. In general, the results show that the shade planting program has been successful. Sites that are not meeting standards are targeted for remedial action (CWS 2011). 


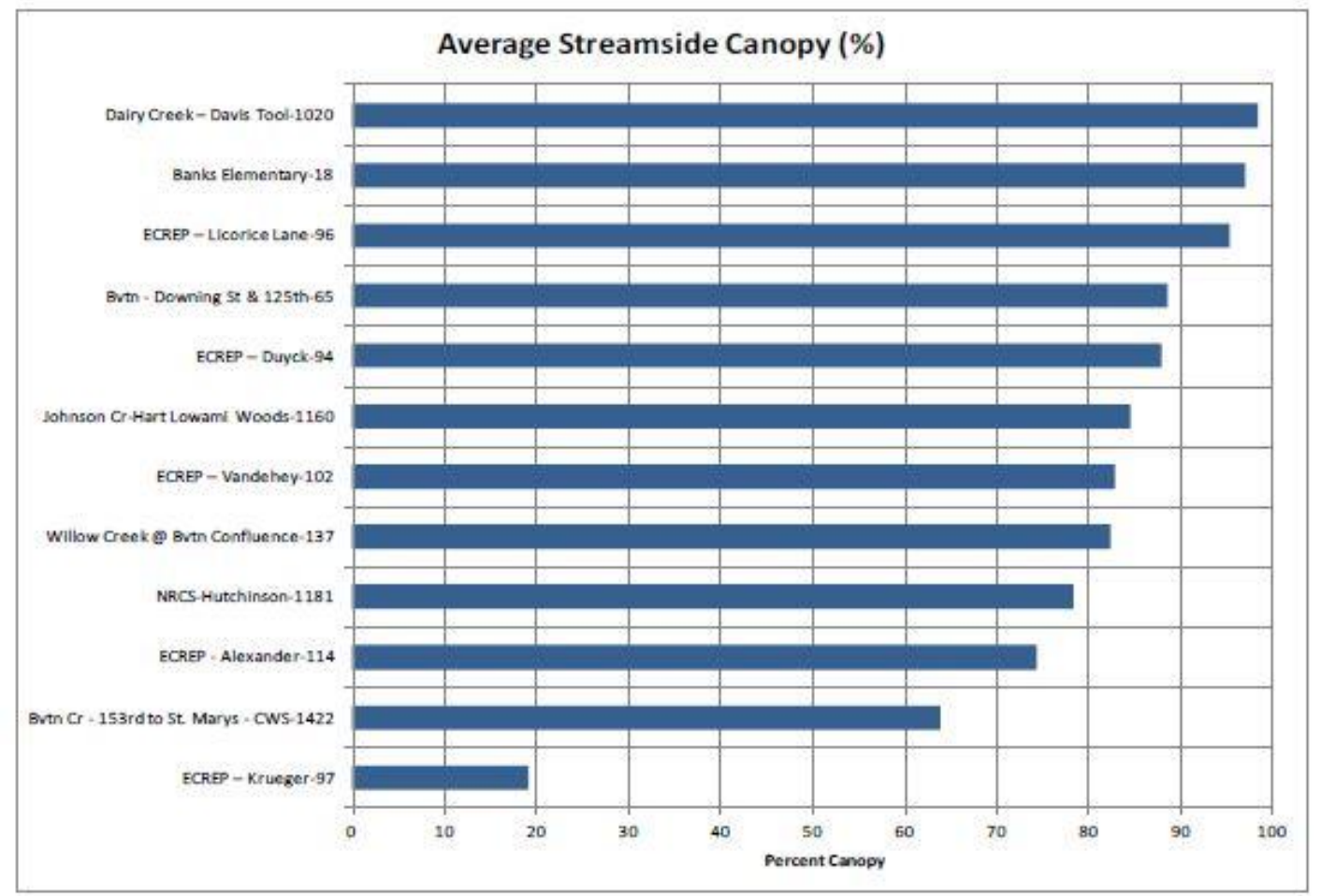

Figure 22: Streamside canopy at 2006 planting sites (Source: CWS 2011)

Other planting performance measures include stocking level (planting density) and amount of invasive species cover (table 8).

Table 8: Riparian vegetation performance measures (Source: Roll et al. 2010)

\begin{tabular}{|l|l|l|}
\hline Parameter & Measure & Performance Target \\
\hline $\begin{array}{l}\text { Native Tree and } \\
\text { Shrub Density }\end{array}$ & Tree and Shrub Counts & $\begin{array}{l}60 \% \text { of tree and shrub target stocking } \\
\text { density by Year 5. Stocking density } \\
\text { rates are unique to each plant } \\
\text { community type. }\end{array}$ \\
\hline $\begin{array}{l}\text { Invasive } \\
\text { Species Cover }\end{array}$ & $\begin{array}{l}\text { Visual estimation of } \\
\text { aerial cover }\end{array}$ & $\begin{array}{l}\text { Target species are placed in cover } \\
\text { categories and evaluated to ensure } \\
\text { cover does not increase over time. }\end{array}$ \\
\hline
\end{tabular}

During the first five years of the planting program (2004-2008), 82\% of the CWS

planting projects were meeting these performance measures (Roll et al. 2010) (table 9). 
Table 9: Shade planting performance results (Source: Roll et al. 2010)

\begin{tabular}{|lccc|}
\hline Program & $\begin{array}{c}\text { Stream Mile } \\
\text { Planted }\end{array}$ & $\begin{array}{c}\text { \# of Trees and } \\
\text { Shrubs Planted }\end{array}$ & $\begin{array}{c}\text { Percentage of } \\
\text { Projects Meeting } \\
\text { Performance } \\
\text { Standards }\end{array}$ \\
\hline ECREP & 9.9 & 449,000 & $82 \%$ \\
Community-Tree-For-All & 4.1 & 276,000 & $60 \%$ \\
Captial Improvement & 15.2 & 892,000 & $89 \%$ \\
\multicolumn{1}{c}{ Totals } & 29.2 & $1,617,000$ & $82 \%$ (Average) \\
\hline
\end{tabular}

\section{Calculating thermal credits}

Flow augmentation and stream shading reduce the thermal load received by streams.

CWS uses the reduction in thermal load from flow augmentation and shade to offset the thermal load from WWTF effluent.

The basis for flow augmentation credit is the reduction in thermal load attributed to reservoir releases. The thermal load reduction is the calculated difference between stream temperatures with and without flow augmentation.

Shade credits are based on the reduction in direct solar radiation reaching a stream.

Canopy cover percentage (effective shade) is used as a surrogate for reduction in solar radiation. Thermal load reduction is unshaded potential radiation times canopy cover percentage. Modeled solar radiation for an unshaded stream segment in the Tualatin basin is $480 \mathrm{kcals} / \mathrm{ft}^{2} / \mathrm{day}$. If site canopy cover averages $90 \%$, the reduction in thermal load would be $432 \mathrm{kcals} / \mathrm{ft}^{2} / \mathrm{day}$ for that site (480 kcals/ft²/day times 0.90) (CWS 2005a). 
CWS receives thermal credits for shading immediately after planting. It will take time for the new vegetation to reach its shading potential. To account for this, a trading ratio is applied that reduces the shading credit received by CWS. For streams more than seven feet wide, the trading ratio is 0.5 times the calculated thermal load reduction from shading. Streams less than seven feet wide use a trading ratio of 1.0 (DEQ 2001).

\section{Agricultural water temperature management}

Under Oregon's Agricultural Water Quality Management Act (AgWQMA), the Oregon Department of Agriculture (ODA) is responsible for managing pollution from agricultural sources. For watersheds that contain water quality limited streams and are subject to a TMDL, the ODA establishes an Agricultural Water Quality Management Area. For each management area, ODA partners with the local SWCD to create and implement an Agricultural Water Quality Management Plan to bring affected stream into compliance with the TMDL. The first Tualatin basin management plan was created in 1996, and last updated in 2010 (ODA 2010). A draft of the 2014 update has been recently released (ODA 2014a).

Most agricultural pollution comes from nonpoint sources. Under the AgWQMA, the ODA has established a set of administrative rules governing activities near streams. While the focus of the rules is aimed at reducing sediment and nutrient pollution from agricultural runoff, two rules directly affect stream temperature: a requirement to allow vegetation to develop along perennial streams, and a ban on irrigation discharges between May 1 and October 31 (ODA 2010). 
The Tualatin SWCD is the local management agency designated to implement the projects and programs included in the management plan (ODA 2010). The SWCD relies primarily on voluntary measures to achieve the goals of the plan; SWCD implementation activities include education, incentive programs to fund streamside planting including ECREP and VEGBAC, and development of voluntary farm water quality management plans (ODA 2010). The ODA is responsible for enforcement actions through a complaint-driven process (TVWD 2013).

The Tualatin basin management plan encourages riparian stream planting. However, the AgWQMA requires only that farm activities do not interfere with the growth of riparian vegetation (ODA 2010). Shade planting projects on agricultural lands that were funded by incentive programs from 2005-2013 included over 30 miles of streams in the Tualatin basin. The draft Tualatin management plan contains a goal to have over 100 stream miles with owners enrolled in incentive-based planting programs by 2020 (ODA 2014a).

\section{Forestry water temperature management}

The Oregon Department of Forestry (ODF) is the DMA responsible for temperature management on state and private timberlands. Water pollution rules and best practices governing private timberlands are found in the FPA, while state timberlands are managed under the rules of the FMP. Both the FPA and FMP set standards for forested stream buffer widths and density; buffer width criteria are more stringent under the FMP than the FPA (figure 23). Forestry activities compliant with the FPA and FMP are considered to be compliant with DEQ pollution rules (IMST 2004). 


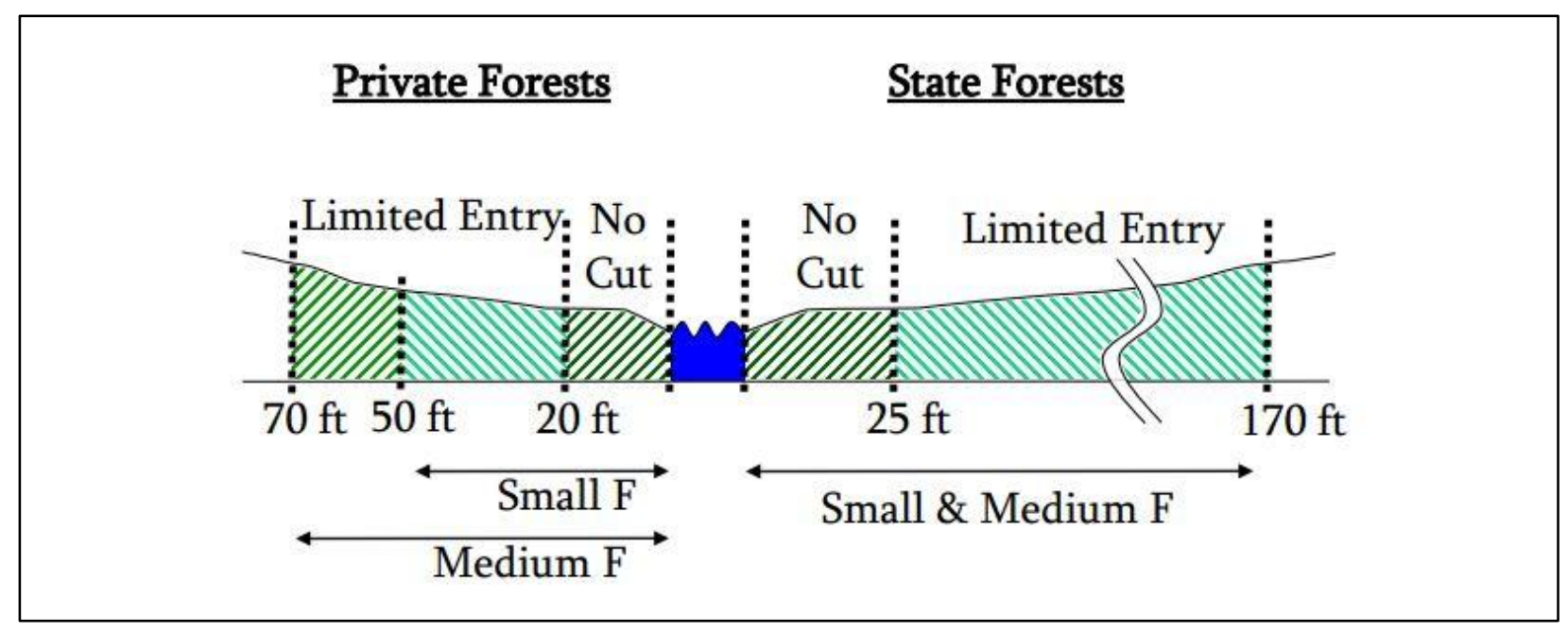

Figure 23: Private and state riparian forest buffer widths (source: Groom and Daugherty 2011b)

Forested streams are classified by three different uses and three different stream sizes. Use categories include fish-bearing (type F), non-fish bearing (type N), and domestic use (type D); size classifications are small (annual flow rate less than $2 \mathrm{cfs}$ ), medium (flow rate from 2 $10 \mathrm{cfs}$ ), and large (flow rate greater than $10 \mathrm{cfs}$ ). Riparian management area widths are based on these stream classifications (ODF 2014a).

Vegetation goals for fish bearing streams are to retain vegetation that, over time, will be similar to that of mature unmanaged stands. Non-fish bearing streams upstream of fish bearing streams also have a requirement to maintain sufficient vegetation to support functions that are important to downstream fish, including maintaining cool water temperatures and encouraging large woody debris recruitment. There is also a requirement to maintain all understory vegetation within 10 feet and all trees within 20 feet of the high water level, and all trees that lean over the channel of fish-bearing streams (ODF 2014b).

DEQ biologically-based temperature criteria applicable to forestry activities include the spawning temperature standard $\left(55.4^{\circ} \mathrm{F}\right)$ and the migration and rearing temperature standard 
$\left(66.4{ }^{\circ} \mathrm{F}\right)$. Stream temperatures cannot exceed the level required for fish, and cannot be increased by greater than $0.3^{\circ} \mathrm{F}$. In addition, a Protecting Cold Water (PCW) criterion also applies.

Forestry activities cannot increase water temperatures more than $0.5^{\circ} \mathrm{F}$ in streams where ambient water temperatures are less than the biologically-based criteria (DEQ 2014b).

ODF initiated the Riparian Function and Stream Function (RipStream) project to verify that the FMP and FPA regulations resulted in compliance with DEQ stream temperature rules. The study monitors stream temperatures above and below 15 public and 18 private logging operations to assess whether differences in buffer requirements resulted in detectable changes in temperature (RipStream 2009). The project determined that two years after harvest, pre- and post-harvest stream temperature patterns were similar for operations in state forests; stream temperatures increased following harvest on private lands. The increase was attributed to a decrease in stream shading following logging operations on private lands (Groom et al. 2011a).

\section{Discussion - Is it working?}

From 2004 to 2013, the CWS shade program planted about 48 miles of riparian vegetation. In July and August of 2012, flow augmentation volume was an average of 41.8 CFS. Thermal credits for flow augmentation (1138 million kcals/day) more than offset the average WWTF effluent thermal load of 973 million kcals/day. Still, 2012 stream temperatures on the Tualatin River from the Rood Bridge gage (RM 38.4) downstream to the West Linn gage (RM 1.75) exceeded migration and rearing temperature criteria for much of July and August, as did temperatures in the lower reaches of major tributary streams (table 10). Both the Rock Creek and Durham treatment facilities were releasing warmed effluent into a river that was already exceeding temperature standards. 
Table 10: Selected Tualatin basin stream temperatures (Compiled from data in CWS 2012a)

\begin{tabular}{|c|c|c|c|c|c|c|c|}
\hline \multicolumn{8}{|c|}{ Mean / Maximum stream Temperatures $\left({ }^{\circ} \mathrm{F}\right)$ July/August 2012} \\
\hline \multirow[t]{2}{*}{ Gage } & \multirow[t]{2}{*}{ Location } & \multicolumn{2}{|c|}{ Mean } & \multicolumn{2}{|c|}{ Max } & \multirow[t]{2}{*}{ Days exceeding criteria } & \multirow[t]{2}{*}{ Notes } \\
\hline & & July & August & July & August & & \\
\hline \multicolumn{8}{|c|}{ Tualatin River } \\
\hline DLLO & RM 58.8 & 53.2 & 52.2 & 55.6 & 52.7 & & \\
\hline ROOD & RM 38.4 & 63.9 & 62.8 & 66.7 & 67.6 & 23 days $>64.4^{\circ} \mathrm{F}$ & \\
\hline FRMO & RM 33.3 & 66.7 & 66.7 & 69.4 & 70.9 & 49 days $>64.4^{\circ} \mathrm{F}$ & \\
\hline WSLO & RM 1.75 & 71.1 & 72.7 & 74.3 & 76.1 & 62 days $>64.4^{\circ} \mathrm{F}$ & \\
\hline \multicolumn{8}{|c|}{ Gales Creek } \\
\hline $\mathrm{GCCH}$ & RM 12.36 & 63.1 & 65.3 & 66.4 & 71.2 & 30 days $>64.4^{\circ} \mathrm{F}$ & \\
\hline GALES & RM 2.36 & 66.7 & 68.0 & 70.7 & 73.8 & 46 days $>64.4^{\circ} \mathrm{F}$ & \\
\hline \multicolumn{8}{|c|}{ Dairy Creek } \\
\hline DCSR & RM 6.02 & 61.3 & 63.9 & 65.8 & 67.5 & 13 days $>64.4^{\circ} \mathrm{F}$ & 2011 data \\
\hline DAIRY & RM 2.06 & 62.2 & 64.6 & 65.7 & 68.4 & 19 days $>64.4^{\circ} \mathrm{F}$ & 2011 data \\
\hline \multicolumn{8}{|c|}{ Rock Creek } \\
\hline $\mathrm{RCBL}$ & RM 8.9 & 67.3 & 65.7 & 69.8 & 71.6 & 50 days $>64.4^{\circ} \mathrm{F}$ & \\
\hline RCTV & RM 1.2 & 66.4 & 66.6 & 69.6 & 71.6 & 46 days $>64.4^{\circ} \mathrm{F}$ & \\
\hline \multicolumn{8}{|c|}{ Fanno Creek } \\
\hline FCTW & RM 7.3 & 66.2 & 67.0 & 69.4 & 72.3 & 46 days $>64.4^{\circ} \mathrm{F}$ & \\
\hline FANO & RM 1.2 & 67.1 & 67.5 & 70.3 & 72.5 & 47 days $>64.4^{\circ} \mathrm{F}$ & \\
\hline
\end{tabular}

There are a number of possible explanations why steam temperatures are still exceeding criteria. Projected temperature decreases are based on modeling, and it is possible that the model results are inaccurate. Inter-annual variability in streamflow, air temperature and precipitation patterns could be a factor. Forestry, agriculture and urban development could be causing disturbance of existing riparian vegetation that increased solar heat loading. However, the most likely explanation for continued elevated stream temperatures is that there is not enough shade established in the basin to reduce stream temperatures.

CWS performed shade monitoring at each site beginning five years after planting. Shade reports show that for the 2004 to 2010 planting season 44 of 54 sites (greater than $80 \%$ ) had established canopy cover greater than $50 \%$. Shade planting efforts are producing canopy cover, 
but may not reach full shading potential until 20 years after initial planting (CWS 2005a). But even at full shading potential, the current CWS planting and flow augmentation program cannot bring Tualatin basin streams into compliance with temperature standards. Anthropogenic heat loading in the Tualatin basin is about 7,848 million kcals/day, divided between nonpoint sources (6,924 million kcals/day) and point sources (923 million kcals/day) (figure 24). Even if all point source heat loads are offset by shade planting, the nonpoint source thermal load would still account for nearly $88 \%$ of the anthropogenic heat load in the Tualatin basin (DEQ 2001).

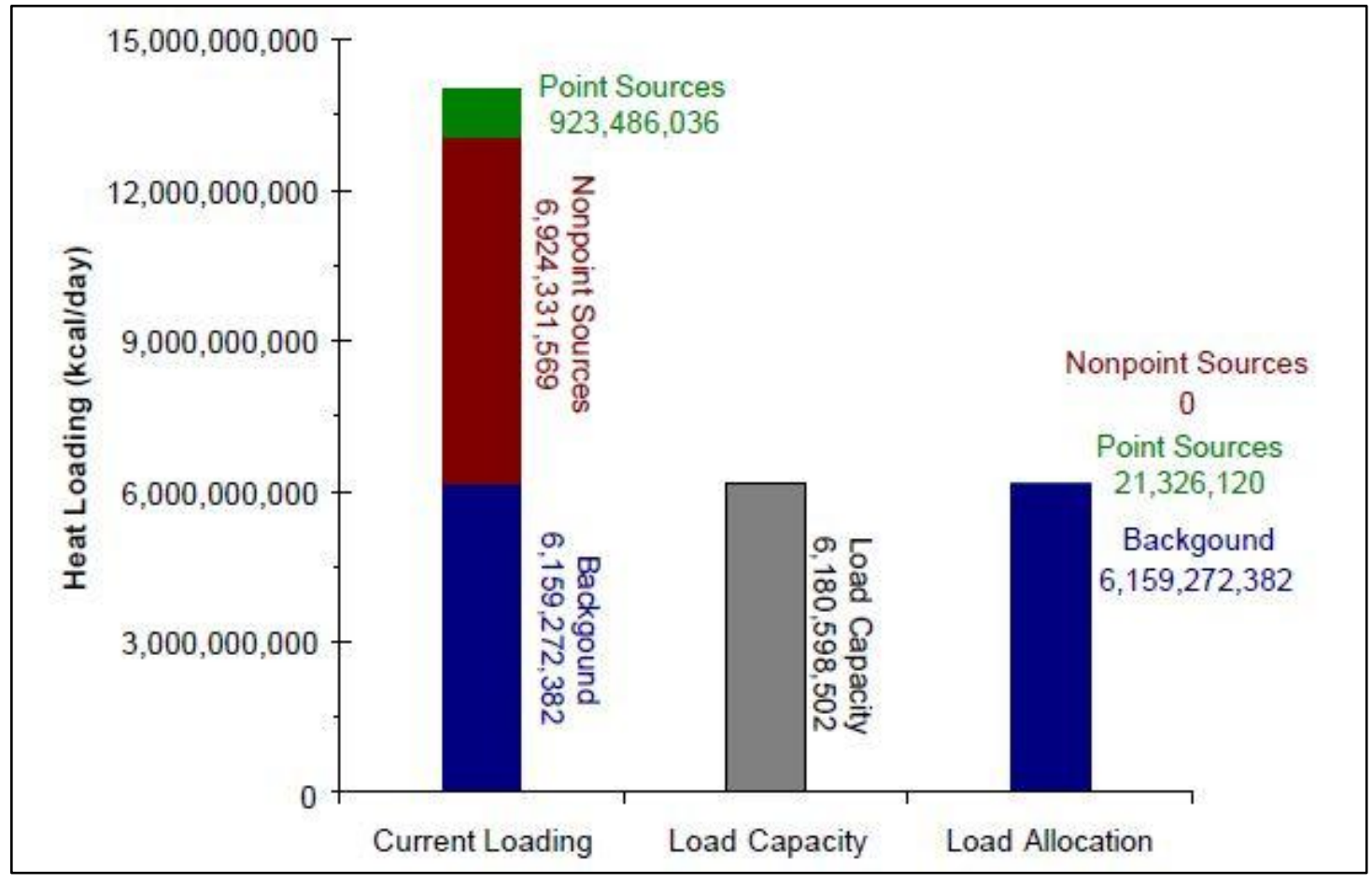

Figure 24: Tualatin basin heat loading sources (Source: DEQ 2001)

Nonpoint source heat loading is not a problem unique to the Tualatin basin: "Nonpoint source pollution is the leading source of water quality impairment in the United States...the vast majority of our nation's impaired waters have no possibility of being restored unless the nonpoint sources are effectively remediated" (EPA 2011). Urban, agricultural and forestry 
disturbance to riparian vegetation all contribute to nonpoint source heat load. In the Tualatin basin, most of the anthropogenic nonpoint source heat load is from streams flowing through areas where the dominant land use is agriculture or forestry (DEQ 2001).

CWS has projected that 20 years after planting, the 48 miles of shade planting from 20042013 will reduce thermal loading by 737.3 million kcals/day (CWS 2004, CWS 2005b, CWS 2006, CWS 2007,CWS 2008, CWS 2009, CWS 2010, CWS 2011, CWS 2012c, CWS 2013) (table 11). This averages about $15.3 \mathrm{kcals} /$ day per stream mile planted.

Table 11: Projected 20 year CWS shade planting thermal load reduction (Data sources: CWS 2004, CWS 2005b, CWS 2006, CWS 2007, CWS 2008, CWS 2009, CWS 2010, CWS 2011, CWS 2012c, CWS 2013)

\begin{tabular}{|c|c|c|}
\hline \multicolumn{3}{|c|}{ Projected Thermal Load Reduction 20 year after planting } \\
\hline million kcals/day & planting year & miles planted \\
\hline 60.3 & 2004 & 5.49 \\
\hline 110.0 & 2005 & 6.91 \\
\hline 150.0 & 2006 & 8.66 \\
\hline 150.0 & 2007 & 8.24 \\
\hline 100.0 & 2008 & 5.78 \\
\hline 24.0 & 2009 & 3.50 \\
\hline 43.0 & 2010 & 2.76 \\
\hline 41.0 & 2011 & 1.53 \\
\hline 17.0 & 2012 & 2.09 \\
\hline 42.0 & 2013 & 3.08 \\
\hline 737.3 & Total & 48.04 \\
\hline $\begin{array}{l}\text { Data Source: } 2004 \text { - } 2013 \text { Clean Wat } \\
\text { Management Plan \& Credit Trading }\end{array}$ & $\begin{array}{l}\text { er Services Tem, } \\
\text { g Activites Annu }\end{array}$ & $\begin{array}{l}\text { perature } \\
\text { Ial Reports }\end{array}$ \\
\hline
\end{tabular}

Based on the CWS shade planting heat load reduction rate of $15.3 \mathrm{kcals} /$ day per stream mile, reducing the total nonpoint source heat load in the Tualatin basin to zero by shading will require about 451 additional stream miles of riparian planting (table 12), more than nine times the number of stream miles planted by the CWS shade planting program to date. 
Table 12: Shade miles needed to offset Tualatin basin nonpoint source thermal loading (Data Source: DEQ 2001, CWS 2004, CWS 2005b, CWS 2006, CWS 2007, CWS 2008, CWS 2009, CWS 2010, CWS 2011, CWS 2012c, CWS 2013)

\begin{tabular}{|l|r|}
\hline \multicolumn{2}{|c|}{ Shade miles needed to offset nonpoint source heat load } \\
\hline $\begin{array}{l}\text { Tualatin basin nonpoint source } \\
\text { thermal load (million kcals/day) }\end{array}$ & $6,924.3$ \\
\hline $\begin{array}{l}\text { Calculated CWS average heat load } \\
\text { reduction per mile (million kcals/day) }\end{array}$ & 15.3 \\
\hline $\begin{array}{l}\text { Calculated shade miles need to offset } \\
\text { Tualatin basin nonpoint source }\end{array}$ & 451.2 \\
\hline $\begin{array}{l}\text { Data Sources: } 2004 \text {-2013 Clean Water Services Temperature Management Plan } \\
\text { \& Credit Trading Activites Annual Reports, DEQ Tualatin Subbasin TMDL 2001 }\end{array}$ \\
\hline
\end{tabular}

CWS has provided financial assistance for about 21 of the 33 miles of rural riparian shade planting completed from 2004 - 2013. CWS subsidies for shade planting accounted for greater than $60 \%$ of the Tualatin SWCD revenue in 2012-2013 (SWCD 2013). While CWS continues to have a responsibility to assist in urban shade planting activities, it is not obligated to fund rural shade planting beyond what is required to offset WWTF discharge. The majority of the funding required for future shade planting will need to come from sources other than CWS.

The requirement to establish and maintain vegetative buffers on agricultural streams has been in effect since 2005. Agricultural activities on perennial streams must allow for the "natural or managed regeneration and growth of vegetation (ODA 2010)." In many sites, passive management of riparian areas will not produce site potential shade. Getting shade planting projects to full potential involves ongoing maintenance and monitoring. Invasive plants such as reed canarygrass (Phalaris arundinacea) and himalayan blackberry (Rubus armeniacus) provide minimal shading and can outcompete the native species used in riparian shade planting. Browsing by herbivores like beaver (Castor canadensis), nutria (Myocastor coypus) and blacktailed deer (Odocoileus hemionis) can reduce planting effectiveness. Disease, fire, extreme weather conditions and exotic insects can all affect riparian plant growth and survival. 
Despite educational programs and technical assistance provide by the local SWCDs and their partners, many agricultural landowners remain unaware of the water quality rules that affect them. Incentive programs exist to fund streamside shade projects, but many farmers either do not know about these programs or have declined to participate (ODA 2012). The Tualatin Water Quality Management Plan relies primarily on voluntary measures to meet temperature standards, and enforcement actions have been rare (ODA 2012). In order to reduce the agricultural nonpoint source heat load it is responsible for managing, ODA will need to be more actively involved in stream shading efforts if the temperature criteria in the Tualatin basin are to be met.

In response to concerns that the current programs have been ineffective (particularly its complaint-driven enforcement policy) the ODA has established two new programs to better focus on water quality issues (ODA 2012).

The Strategic Information Areas (SIA) program expands ODA's role in water quality management. The first departure from the existing program is that ODA will conduct a survey to determine the current level of compliance with water quality rules in the SIA. As is done in the current process, the local SWCD and other partners provide educational and technical assistance to help rural landowners achieve compliance using voluntary measures. The other major change is that ODA can now initiate enforcement action on its own if voluntary actions do not resolve issues identified in the compliance survey. A key component of the program is to separate clearly the role of ODA (monitoring and enforcement) from the role of the local SWCD (education and assistance). Two watersheds in Marion and Wasco counties have been chosen to pilot this new program (ODA 2014b). 
The second ODA program being implemented is Agricultural Water Quality

Management Focus Areas. It has been shown that water quality management activities can reduce pollution at a farm scale, but it is difficult to measure the effect of these actions at larger scales (ODA 2012, ODA 2014c). To address this issue, every SWCD in Oregon has chosen a small watershed as a Focus Area, and resources are being applied in those areas in an attempt to provide measureable program results (ODA 2014c).

The Tualatin SWCD has identified the Dairy-McKay Creek subbasin as a focus area for 2013-2015 activities (SWCD 2013) (figure 25). This area was selected because agriculture is a significant land use (39\%) (SWCD 2013) and the major streams within the subbasin are among the highest in the Tualatin basin for percentage of nonpoint source heat load from human sources. (DEQ 2001) (table 13). 


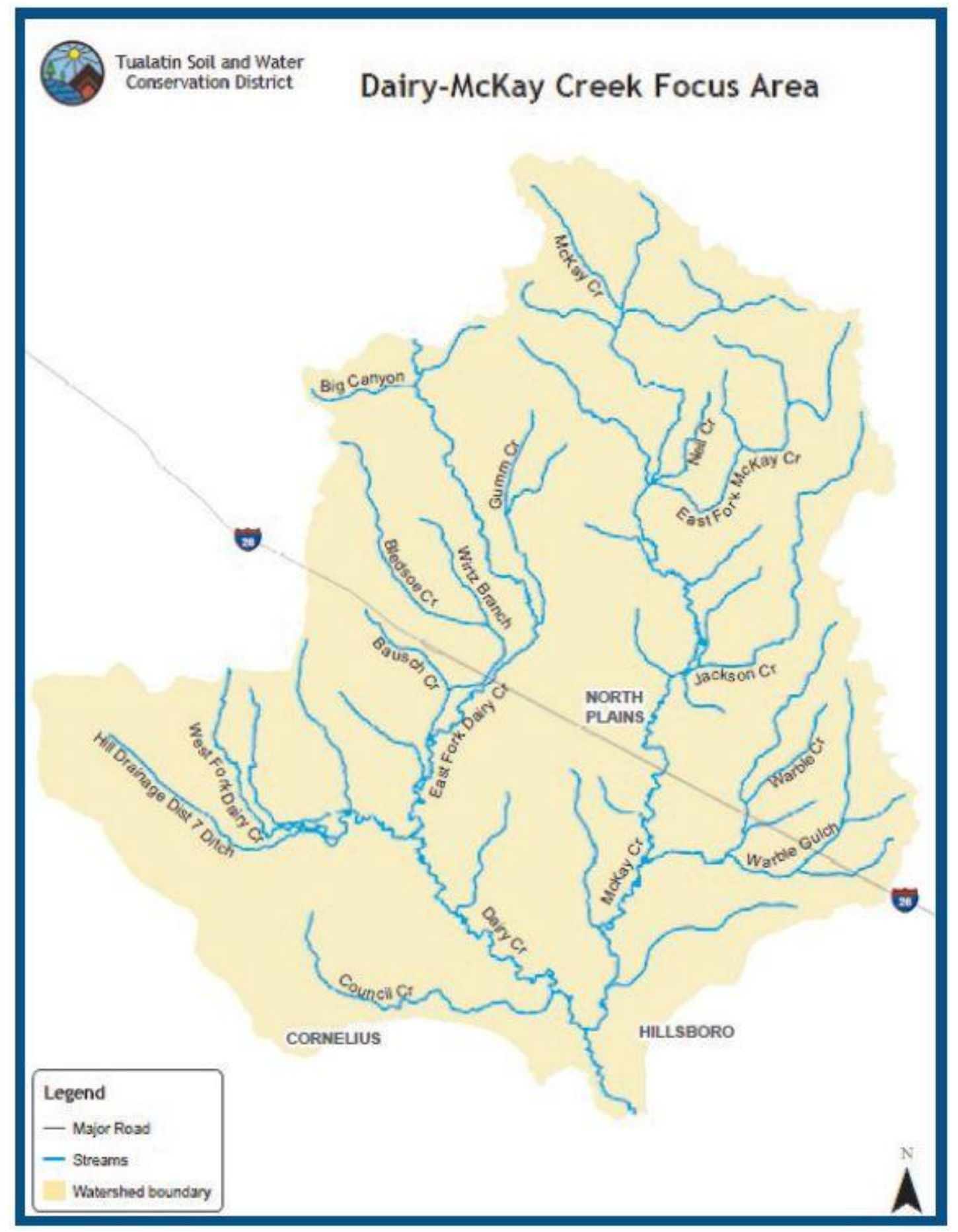

Figure 25: Dairy-McKay Creek Focus Area (Source: SWCD 2013) 
Table 13: Nonpoint source solar radiation for major streams (DEQ 2001)

\begin{tabular}{|c|c|c|c|c|}
\hline Stream & $\begin{array}{c}\text { H Total NPS } \\
\text { Current } \\
\text { Condition } \\
\text { Solar Radiation } \\
\text { Heat Loading } \\
\text { (kcal/day) }\end{array}$ & $\begin{array}{c}\text { HsP NPS } \\
\text { Background } \\
\text { System Potential } \\
\text { Solar Radiation } \\
\text { Heat Loading } \\
\text { (kcal/day) }\end{array}$ & $\begin{array}{c}\text { HAnthro NPS } \\
\text { Anthropogenic } \\
\text { Nonpoint Source } \\
\text { Solar Radiation } \\
\text { Heat Loading } \\
\text { (kcal/day) }\end{array}$ & $\begin{array}{l}\text { Portion of Current } \\
\text { Solar Radiation } \\
\text { Load from } \\
\text { Anthropogenic } \\
\text { Nonpoint Sources }\end{array}$ \\
\hline Tualatin $\mathrm{R}$. & $1.0 \cdot 10^{10}$ & $5.6 \cdot 10^{9}$ & $4.4 \cdot 10^{9}$ & $43.7 \%$ \\
\hline Gales Cr. & $1.1 \cdot 10^{9}$ & $1.8 \cdot 10^{8}$ & $8.8 \cdot 10^{8}$ & $82.9 \%$ \\
\hline WF Dairy $\mathrm{Cr}$. & $3.5 \cdot 10^{8}$ & $2.2 \cdot 10^{7}$ & $3.3 \cdot 10^{8}$ & $93.8 \%$ \\
\hline EF Dairy $\mathrm{Cr}$. & $6.9 \cdot 10^{8}$ & $1.1 \cdot 10^{8}$ & $5.8 \cdot 10^{8}$ & $84.6 \%$ \\
\hline Dairy $\mathrm{Cr}$. & $4.3 \cdot 10^{8}$ & $8.1 \cdot 10^{8}$ & $3.5 \cdot 10^{8}$ & $81.2 \%$ \\
\hline McKay Cr. & $2.8 \cdot 10^{8}$ & $3.8 \cdot 10^{7}$ & $2.4 \cdot 10^{8}$ & $86.4 \%$ \\
\hline Rock Cr. & $4.5 \cdot 10^{\prime}$ & $2.2 \cdot 10^{\prime}$ & $2.3 \cdot 10^{\prime}$ & $51.4 \%$ \\
\hline Beaverton $\mathrm{Cr}$. & $1.1 \cdot 10^{8}$ & $4.3 \cdot 10^{7}$ & $6.6 \cdot 10^{7}$ & $60.6 \%$ \\
\hline Fanno $\mathrm{Cr}$. & $1.2 \cdot 10^{8}$ & $3.8 \cdot 10^{7}$ & $8.3 \cdot 10^{7}$ & $68.5 \%$ \\
\hline Total & $1.3 \cdot 10^{10}$ & $6.2 \cdot 10^{9}$ & $6.9 \cdot 10^{9}$ & $52.9 \%$ \\
\hline
\end{tabular}

The new ODA programs may increase participation in rural shade planting programs.

However, to ensure long-term program success, funding sources other than CWS will need to be in place for planting, monitoring, maintenance, and compliance.

Forestry activities can also increase heat loading, and much of the forest harvest in the Tualatin basin takes place in the uplands near streams that are important spawning habitat. The RipStream study found that current FPA rules governing riparian buffer requirements for forestry activities on private land often resulted in violation of the PCW criterion, while timber operations on state forests governed by FMP buffer rules did not. The Oregon Board of Forestry has been examining the issue for several years; if the Board of Forestry agrees to change the FPA to incorporate new rules to enhance riparian habitat protection, it is scheduled to approve the new rules at its July 2015 meeting (ODF 2014c).

Future developments may influence stream temperatures and the measures being taken to mitigate them, including drought, seismic risks, updated treatment technology, water demand, climate change, and changes to laws and rules. 
CWS is highly dependent on flow augmentation to offset WWTF releases; flow augmentation accounted for $73.5 \%$ of the 2013 thermal credits claimed by CWS in 2013 (CWS 2013). Drought conditions during the winter of 2000 - 2001 left Barney Reservoir at 56\% of capacity and Scoggins Reservoir at 52\% of capacity; the 2001 CWS allocation for flow augmentation was 4,036 acre-feet, only $29 \%$ of normal (CWS 2001). Future droughts could impact CWS's ability to meet TMDL requirements.

The population of Tualatin basin in increasing; it is projected that an additional 40,000 acre feet of water will be needed by 2050 (Murdock 2004). The preferred option had been to increase the capacity of Hagg Lake by raising the height of Scoggins Dam by forty feet, which was expected to cost about $\$ 130$ million (Obermeyer 2004). However, a 2007 Bureau of Reclamation study discovered seismic hazards at the dam that will require remediation that will cost $\$ 300$ million over the cost of raising the level of the dam (Oregon Live 2013). Due to the high costs and uncertainty about the feasibility of a dam raise, the JWC and TVWD are now committed to the Mid-Willamette Supply Option, which will pipe water from the Willamette River near Wilsonville for use in the Tualatin Valley (TVWD 2013). Even without the dam raise, it is important to remedy seismic issues at Scoggins Dam. Water supplied from Hagg Lake is still needed to meet existing demand, and Scoggins Dam has a hazard rating of "high" by the Oregon Water Resources Board, meaning that dam failure could result in the loss of human life (Oregon Department of Water Resources 2014).

Capital projects at CWS treatment facilities may affect stream temperatures and how they are mitigated. A 95-acre natural treatment system (NTF) is under construction at the Forest Grove WWTF that will allow effluent discharge during summer, and CWS forecasts that effluent released from the NTF to the Tualatin River will not have an impact on downstream 
temperatures (figure 26). The NTF includes a series of treatment ponds and natural wetlands that are being modified to enhance final treatment and cooling of effluent. Treated effluent from the Hillsboro and Forest Grove WWTFs will be piped to the NTF for final treatment and cooling, instead of being piped to the Rock Creek WWTF (CWS 2013). Utilizing the NTF will reduce the volume of effluent being released at the Rock Creek facility. CWS is also building a cogeneration facility at the Durham WWTF and updating the existing cogeneration facility at the Rock Creek WWTF. Both of these projects could reduce the thermal load by dissipating a portion of the heat load at the facilities to the atmosphere (CWS 2013). If projected increase in summer effluent release volume and temperature are moderated by these projects, it may reduce the planting required by CWS to offset projected WWTF thermal load increases.

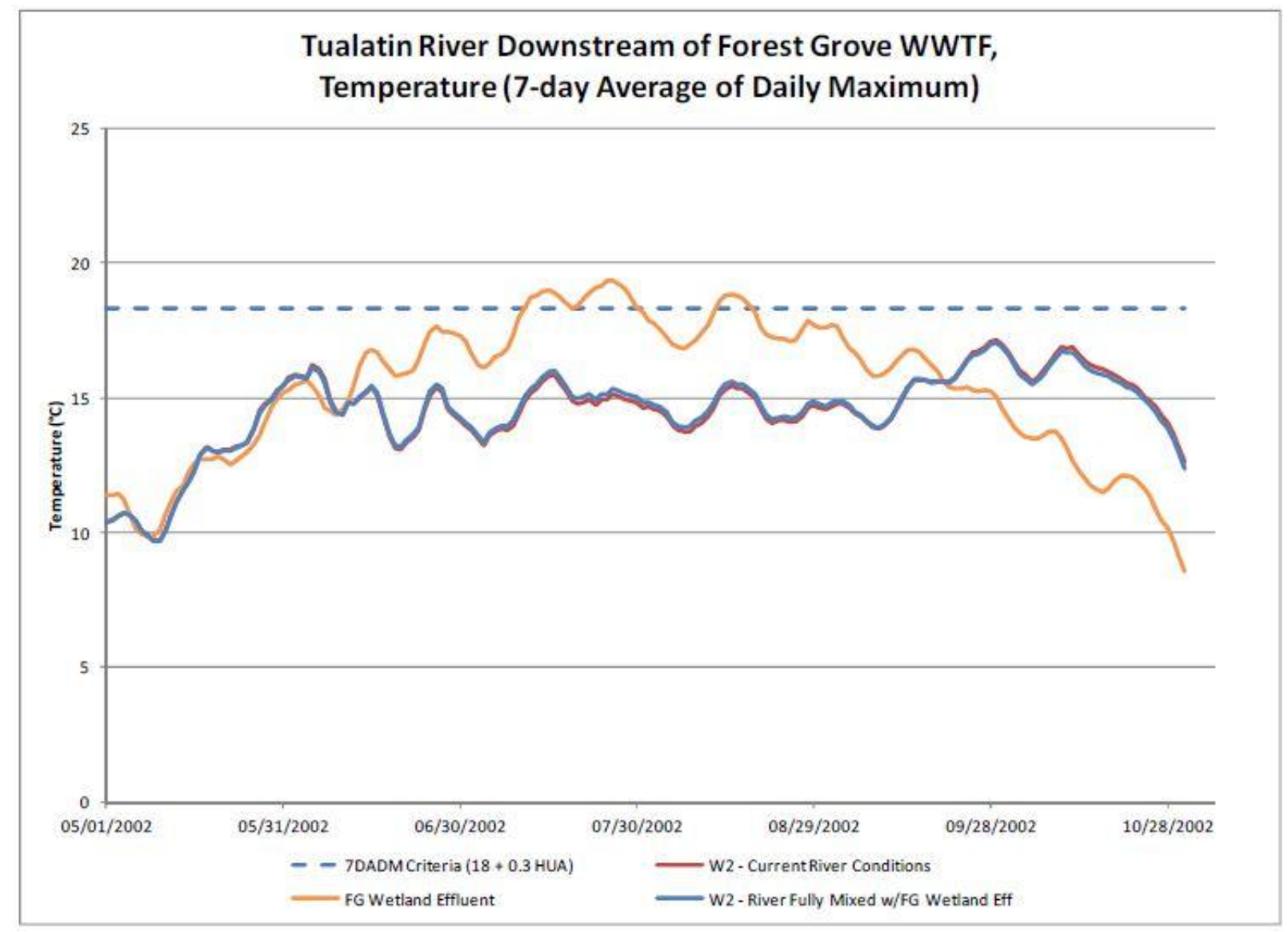

Figure 26: Projected temperatures downstream of Forest Grove WWTF NTF (Source: CWS 2012b) 
Climate change could dramatically change stream temperature dynamics in the Tualatin basin. Modeling has predicted that climate change in the basin could increase winter streamflow by $10 \%$ and decrease summer streamflow by $37 \%$ in the 2070 s, and increased variability in flow rates are also likely (Praskievicz and Chang 2011). Increased winter streamflows may result in greater amounts of water available for reservoir storage, but decreased summer flows would require that greater amounts of water be available for flow augmentation and other uses. Climate change may also affect the plant species being planted to provide stream shading. Native plants have evolved to adapt to historic climate conditions, they may not adapt well to a rapidlychanging climate. Climate change could have a more severe effect in watersheds like the Willamette where summer streamflow is driven by melting snowpack. If climate change significantly affects Willamette River streamflow, this could reduce the availability of water from the Mid-Willamette Supply Option project.

Finally, changes in temperature criteria could have an impact on water temperatures. A revision to Oregon's water temperature standard was introduced in 2003 and approved by the EPA in 2004 (EPA 2013). If the DEQ determined that the temperature of a stream under historical natural thermal conditions was higher than the numeric biological standard, it could replace the biological standard with the "natural conditions" standard (DEQ 2011).

A lawsuit was filed by Northwest Environmental Advocates challenging the EPA's acceptance of the new natural conditions criteria. The suit was upheld by an Oregon Federal District Court in 2012 and in 2013, the EPA disapproved of Oregon's use of the natural conditions criteria (EPA 2013). Because of this decision, the Tualatin Basin is still operating under the requirements of the 2001 temperature TMDL, while TMDLs for other pollutants were included in the 2012 TMDL update (DEQ 2012). 
In the court's opinion, the natural conditions criteria would supplant rather than supplement the science-based numerical standards that had been determined to protect salmonids, and significant uncertainty exists in the methods used to estimate historical temperatures (US District Court 2012). Moreover, it found that "the natural conditions criteria attempts to restore one aspect of Oregon's historical water conditions (higher temperatures in some waterbodies) without restoring the other conditions that allowed salmonids to survive (US District Court 2012)." Historical water temperatures in the Tualatin basin may have exceeded the current temperature criteria, but human disturbance has significantly altered the basin's hydrology and destroyed much of the cold-water refugia salmonids require to tolerate elevated temperatures.

The watershed-based temperature management plan implemented by CWS has not yet had a measureable effect on stream temperatures in the Tualatin basin, but that does not mean that salmon habitat has not been improved by the shade planting program. Riparian vegetation provides many other ecological benefits beyond reducing stream heating.

Riparian vegetation helps stabilize streambanks, reducing erosion and trapping sediments. It provides a source of woody debris that provides cover for fish. Riparian vegetation intercepts surface runoff, reducing the load of sediments and nutrients reaching the stream. It can alter stream hydrology by changing flow patterns and enhancing groundwater exchange. Riparian vegetation increases the amount of organic matter in the stream. Increased vegetation increases the population and diversity of macroinvertebrate assemblages, making more food resources available to fish. It is beneficial to both aquatic and terrestrial ecosystems (Lyons et al. 2000). 


\section{Summary}

To date, efforts to manage stream temperatures have improved salmon habitat, but have not reduced stream temperatures. Salmonid species require cool water to thrive. Summer water temperatures in the Tualatin basin are often higher than optimum for salmonids. The warm, dry summer climate in the basin reduces natural streamflow and increases the amount of direct solar radiation reaching streams, causing stream temperatures to rise. Nearly 200 stream miles in the Tualatin basin are water quality impaired for temperature, and disturbance of riparian vegetation is the primary cause for elevated stream temperatures.

Clean Water Services is the surface water management agency for the urbanized portions of the Tualatin basis. Discharge of treated effluent from its wastewater treatment facilities increases stream temperatures. CWS entered into an agreement with the DEQ to offset the point source heat load from the treatment facilities using a combination of flow augmentation and riparian shade planting.

The largest heat load source in the Tualatin basin is direct solar radiation. Heat load in streams can be reduced by increasing water volume and by decreasing solar radiation. CWS has planted around 48 stream miles of riparian vegetation to offset its treatment facility effluent releases. However, Tualatin basin streams temperatures still do not meet temperature criteria. The CWS planting sites have not matured to their full shading potential, and they only offset the point source effluent releases. Nonpoint sources of heat load account for nearly $88 \%$ of the basin's total heat load. Reducing the nonpoint source heat load by stream shading alone would require an additional 451 miles of riparian shade planting. 
Shade planting on agricultural streams has the highest potential for reducing stream temperatures. Programs exist that compensate landowners for providing riparian shade vegetation, but many farmers are either unaware of agricultural water quality rules or have declined to participate. New ODA programs may increase landowner participation and help reach water quality criteria. Factors that could affect future Tualatin basin stream temperatures include climate change, increased water demand, seismic risks to dams, changes in treatment technology and changes to pollution laws and rules. Though efforts to date have not solved the problem of excessive stream temperatures, additional planting of riparian shade should provide cooler streams and improved salmonid habitat.

\section{References}

Angilletta, M., E. Steel, K. Bartz, J. Kingsolver, M. Scheuerell, B. Beckman and L. Crozier. 2008. Big dams and salmon evolution: changes in thermal regimes and their potential evolutionary consequences. Evolutionary Applications 1: 286-299.

Beauchamp, D. 2009. Bioenergetic ontogeny: Linking climate and mass-specific feeding to lifecycle growth and survival of salmon. American Fisheries Society Symposium 70, 2009.

Bjornn, T. and D. Reiser. 1991. Habitat requirements of salmonids in streams. American Fisheries Society Special Publication 19: 83-128.

Boyd, M. and D. Sturdevant. 1997. The scientific basis for Oregon's stream temperature standard: Common questions and straight answers. Oregon Department of Environmental Quality, Salem, Oregon.

Carson, D. and C. Nale. 2012. Water Supply Evaluation Project: Technical Memorandum 03 Water Supply Needs. City of Hillsboro, Hillsboro, Oregon.

Chang, H. 2007. Comparative streamflow characteristics in urbanizing basins in the Portland Metropolitan Area, Oregon, USA. Hydrological Processes 21: $211-222$.

Cochran, B. and C. Logue. 2011. A watershed approach to improve water quality: case study of Clean Water Services' Tualatin River program. Journal of the American Water Resources Association 47 (1): 29-38.

Clean Water Services (CWS). 2001. Tualatin River Flow Management Committee 2001 Annual Report. Clean Water Services, Hillsboro, Oregon.

. 2004. Temperature Management Plan and Credit Trading Activities 2005 Annual Report.

Clean Water Services, Hillsboro, Oregon.

. 2005a. Revised Temperature Management Plan. Clean Water Services, Hillsboro, Oregon. . 2005b. Temperature Management Plan and Credit Trading Activities 2010 Annual Report.

Clean Water Services, Hillsboro, Oregon. 
. 2006. Temperature Management Plan and Credit Trading Activities 2006 Annual Report. Clean Water Services, Hillsboro, Oregon.

. 2007. Temperature Management Plan and Credit Trading Activities 2007 Annual Report.

Clean Water Services, Hillsboro, Oregon.

. 2008. Temperature Management Plan and Credit Trading Activities 2008 Annual Report. Clean Water Services, Hillsboro, Oregon.

. 2009. Temperature Management Plan and Credit Trading Activities 2009 Annual Report.

Clean Water Services, Hillsboro, Oregon.

. 2010. Temperature Management Plan and Credit Trading Activities 2010 Annual Report.

Clean Water Services, Hillsboro, Oregon.

. 2011. Temperature Management Plan and Credit Trading Activities 2011 Annual Report.

Clean Water Services, Hillsboro, Oregon.

. 2012a. Tualatin River Flow Management Committee 2012 Annual Report. Clean Water

Services, Hillsboro, Oregon.

. 2012b. Basis of design report for the Natural Treatment System at the Forest Grove

Wastewater Treatment Facility. Clean Water Services, Hillsboro, Oregon.

. 2012c. Temperature Management Plan and Credit Trading Activities 2012 Annual Report.

Clean Water Services, Hillsboro, Oregon.

. 2013. Temperature Management Plan and Credit Trading Activities 2013 Annual Report.

Clean Water Services, Hillsboro, Oregon.

Clean Water Act of 1972, 33 U.S.C § 26 (1972).

Endangered Species Act of 1973, 16 U.S.C $§ 1531$ et seq. (1973).

Fish Ex Quality Seafoods. 2014. The life cycle of an Alaska salmon. Fish Ex Quality Seafoods, Anchorage, Alaska. Available at http://www.fishex.com/seafood/salmon/salmon-lifecycles.html (last accessed 29 October 2014).

Fry, J., G. Xian, S. Jin, J. Dewitz, C. Homer, L. Yang, C. Barnes, N. Herold, J, Wickham.2011. Completion of the 2006 National Land Cover Database for the Conterminous United States. Photogrammetric Engineering and Remote Sensing 77(9): 858-864

Groom, J., L. Dent and L. Madsen. 2011a. Stream temperature change detection for state and private forests in the Oregon Coast Range. Water Resources Research 47 W01501.

Groom, J. and P. Daugherty. 2011b. Riparian function and stream temperature (RipStream) project background, status, and findings to date. Presentation to the Oregon Board of Forestry 3 November 2011. Oregon Department of Forestry, Salem, Oregon. Available at http://www.oregon.gov/odf/BOARD/docs/2011_November/BOFMIN_20111103_ATTC H_06.pdf (last accessed 1 Nov 2014).

Holtby, L. 1988. Effects of logging on stream temperatures in Carnation Creek, British Columbia and impacts on the coho salmon (Oncorhynchus kisutch). Canadian Journal of Fisheries and Aquatic Sciences 45: 502-515.

Independent Multidisciplinary Science Team (IMST). 2004. Oregon's water temperature standard and its application: causes, consequences and controversies associated with stream temperature. Technical Report 2004-1 to the Oregon Plan for Salmon and Watersheds. Oregon Water Enhancement Board. Salem, Oregon.

Isaak, D., S. Wollrab, D. Horan and G. Chandler. 2012. Climate change effects on stream and river temperatures across the northwest U.S. from 1980-2009 and implications for salmonid fishes. Climatic Change 2012 (113): 499-524. 
Lyons, J., S. Trimble and L. Paine. 2000. Grass versus Trees: managing riparian areas to benefit streams of central North America. Journal of the American Water Resources Association. 36 (4): 919-930.

Materna, E. 2001. Issue Paper 4: Temperature Interaction. Prepared as part of EPA region 10 temperature water quality guidance development project. EPA-910-D-01-004. US Environmental Protection Agency, Seattle, Washington.

Metro. 2012. Regional Land Information System (RLIS). Metro Data Resource Center, Portland, Oregon.

McCullough, D. 1999. A review and synthesis of effects of alterations to the water temperature regime on freshwater life stages of salmonids, with special reference to Chinook salmon. EPA report 910-R-99-010. US Environmental Protection Agency, Region 10, Seattle, Washington.

McCullough, D., S. Spalding, D. Sturdevant and M. Hicks. 2001. Issue Paper 5: Summary of technical literature examining the physiological effects of temperature on salmonids. Prepared as part of EPA region 10 temperature water quality guidance development project. EPA-910-D-01-005. US Environmental Protection Agency, Seattle, Washington.

Murdock, R. 2004. Tualatin basin water supply feasibility study technical memorandum Tualatin River water balance model: documentation and results. Clean Water Services, Hillsboro, Oregon.

Naiman, R., H. Décamps and M. McClain. 2005. Riparia: Ecology, Conservation, and Management of Streamside Communities. Burlington, MA: Elsevier Academic Press.

Oregon Agricultural Water Quality Management Act of 1993, ORS § 568.900 et seq. (1993).

Oregon Department of Agriculture (ODA). 2010. Tualatin River Subbasin Agricultural Water Quality Management Area Plan. Oregon Department of Agriculture, Salem, Oregon. . 2012. Oregon Agricultural Water Report. Oregon Department of Agriculture, Salem, Oregon.

. 2014a. Tualatin River Subbasin Draft Agricultural Water Quality Management Area Plan. Oregon Department of Agriculture, Salem, Oregon. . 2014b. Tualatin River Subbasin Draft Agricultural Water Quality Management Area Plan. Oregon Department of Agriculture, Salem, Oregon.

. 2014c. Oregon Water Quality Management Plan Strategic Implementation Areas. Oregon Department of Agriculture, Salem, Oregon. Available at

Oregon Department of Environmental Quality (DEQ). 2001. Tualatin Subbasin Total Maximum Daily Load (TMDL). Oregon Department of Environmental Quality, Salem, Oregon. . 2004. National Pollutant Discharge System Permit Numbers 101141, 101142, 101143, 101144 \& MS4. Oregon Department of Environmental Quality, Northwest Region, Portland, Oregon.

2011. Draft Water Quality Report: Tualatin Subbasin Total Maximum Daily Load (TMDL) and Water Quality Management Plan (WQMP). Oregon Department of Environmental Quality, Portland, Oregon.

2012. Tualatin Subbasin Total Maximum Daily Load and Water Quality Management Plan. Oregon Department of Environmental Quality, Portland, Oregon. . 2014a. Water Quality - Water Quality Assessment - Oregon's 2012 Integrated Report Database. Oregon Department of Environmental Quality, Salem, Oregon. Available at http://www.deq.state.or.us/wq/assessment/rpt2012/search.asp (last accessed 29 October 2014). 
. 2014b. Water quality standards: beneficial uses, policies, and criteria for Oregon, Chapter 340, Division 41, Salem, Oregon.

Oregon Department of Forestry (ODF). 2010. Northwest Oregon State Forests Management

Plan. Oregon Department of Forestry, Salem, Oregon.

. 2011. Private forests monitoring report: Riparian function and stream temperature

(RipStream) project - project background, status and findings to date. Oregon

Department of Forestry, Salem, Oregon.

. 2014a. Water protection rules: Vegetation retention along streams. Oregon Administrative

Rules, Chapter 629, Division 635, Salem, Oregon.

. 2014b. Water protection rules: Vegetation retention along streams. Oregon Administrative Rules, Chapter 629, Division 640, Salem, Oregon.

. 2014c. Oregon Board of Forestry Riparian Rule Analysis Workshop 23 June 2014 meeting minutes. Oregon Department of Forestry, Salem, Oregon.

Oregon Department of Water Resources. 2014. Oregon Dam Safety Program Dam Information

Database. Oregon Department of Water Resources, Salem, Oregon. Available at http://apps.wrd.state.or.us/apps/misc/dam_inventory/default.aspx (last accessed 9 November 2014).

Oregon Forest Practices Act of 1971, ORS § 527.736 et seq. (1991).

Oregon Live. 2013. Federal seismic study of Scoggins Dam recommends $\$ 340$ million in construction, water district manager says. The Oregonian newspaper, Portland, Oregon. Available at http://www.oregonlive.com/washingtoncounty/index.ssf/2013/01/federal_seismic_study_ of_scogg.html (last accesses 10 November 2014).

Poole, G. and C. Berman. 2001. An ecological perspective on in-stream temperature: Natural heat dynamics and mechanisms of human-caused thermal degradation. Environmental Management 27 (6): $787-802$.

Praskievicz, S. and H. Chang. 2011. Impacts of climate change and urban development on water resources in the Tualatin River Basin, Oregon. Annals of the Association of American Geographers 101 (2): 249 - 271.

Risley, J. 1997. Relation of Tualatin River water temperatures to natural and human-caused factors. US Geological Survey Water-Resources Investigations Report 97-4071. US Geological Survey, Portland, Oregon.

Roll, B., B. Cordon, P. Guillozet, K. Petersen-Morgan, B. Vaughn and K. Smith. 2010. Sustainable integrated watershed management in the Tualatin basin. Clean Water Services, Hillsboro, Oregon.

Sauter, S., J. McMillan and J. Dunham. 2001. Issue Paper 1: Salmonid behavior and water temperature.. Prepared as part of EPA region 10 temperature water quality guidance development project. EPA-910-D-01-001. US Environmental Protection Agency, Seattle, Washington.

Sinokrot, B. and H. Stefan. 1993. Stream temperature dynamics: measurements and modeling. Water Resources Research 29 (7): 2299 - 2312.

Tree For All. 2014. Jointreeforall.org. Available at http://www.jointreeforall.org (last accessed 7 November 2014).

Tualatin River Watershed Council (TRWC). 2001. Tualatin River Watershed Atlas. Tualatin River Watershed Council, Hillsboro, Oregon. Available at http://trwc.org/wpcontent/uploads/2013/03/Watershed-Atlas.pdf (last accessed 29 October 2014). 
Tualatin Soil and Water Conservation District. 2013. Tualatin Valley Soil and Water District Annual Report July 2012 to June 2013. Tualatin Valley Soil and Water Conservation District, Hillsboro, Oregon.

Tualatin Valley Water District (TVWD). 2013. Ordinance 01-13: An ordinance establishing polices and direction in adding the Mid-Willamette Supply Option to the district's portfolio of water supplies. Tualatin Valley Water District, Beaverton, Oregon.

US Environmental Protection Agency (EPA). 2011. A national evaluation of the Clean Water Act Section 319 program. US Environmental Protection Agency, Washington, DC. . 2013. Disapproval of Oregon's water quality standards: natural Conditions Criteria for Temperature OAR 340-041-0028(8); statewide narrative natural conditions criteria OAR 340-041-0007(2). US Environmental Protection Agency, Region 10, Seattle, Washington.

US Census Bureau. 2014. State and County Quick Facts: Washington County, Oregon. Available at http://quickfacts.census.gov/qfd/states/41/41067.html (last accessed 30 October 2014).

US District Court. 2012. Northwest Environmental Advocates vs. US Environmental Protection Agency, National Marine Fisheries Service and US Fish and Wildlife Service, Case Number 3:05-cv-01876-AC. US District Court Oregon Division, Portland, Oregon.

US Geological Survey (USGS). 2012. National Hydrography Dataset. US Geological Survey, Reston, Virginia. Available at http://viewer.nationalmap.gov/viewer/ (last accessed 5 November 2014).

. 2014. National Water Information System: USGS 14207500 Tualatin River at West Linn, OR Monthly Statistics. US Geological Survey, Reston, V.irginia. Available at http://waterdata.usgs.gov/or/nwis/monthly/?search_site_no=14207500\&amp;agency_cd= USGS\&amp;referred_module=sw\&amp;format=sites_selection_links (last accessed 30 October 2014).

Western Regional Climate Center. 2014. Hillsboro, Oregon 1971 - 2000 Temperature and Precipitation. Western Regional Climate Center, Reno, Nevada. Available at http://www.wrcc.dri.edu/cgi-bin/cliMAIN.pl?orhill (last accessed 30 October 2014). 


\section{Appendix A: Abbreviations}

AgWQMA Agricultural Water Quality Management Act

CFS Cubic feet per second

CIP Capital Improvement Program

CREP Conservation Reserve Enhancement Program

CWA Clean Water Act

CWS Clean Water Services

DEQ Department of Environmental Quality

DMA Designated Management Agency

ECREP Enhanced Conservation Reserve Enhancement Program

EPA Environmental Protection Agency

FMP Oregon State Forest Management Plan

FPA Forest Practices Act

JWC Joint Water Commission

kcals kilocalories

NPDES National Pollutant Discharge Elimination System

NTF Natural Treatment Facility

ODA Oregon Department of Agriculture

ODF Oregon Department of Forestry

PCW Protecting Cold Water

RM River Mile

SIA Strategic Implementation Areas

SWCD Soil and Water Conservation District

TMDL Total Maximum Daily Load

TRWC Tualatin River Watershed Council

TVID Tualatin Valley Irrigation District

TVWD Tualatin Valley Water District

USFS US Fish and Wildlife Service

VEGBAC Vegetated Buffer Areas for Conservation and Commerce

WQMP Water Quality Management Plan

WWTF Wastewater Treatment Facility 


\section{Appendix B: List of Figures, Equations and Tables}

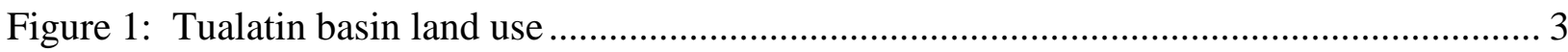

Figure 2: Salmon Life Cycle .......................................................................................... 7

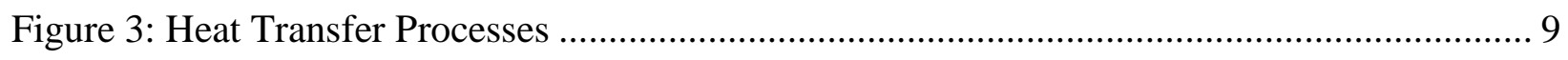

Figure 4: Energy balance for an unshaded stream ......................................................... 11

Figure 5: Stream Cooling Processes ..................................................................................... 11

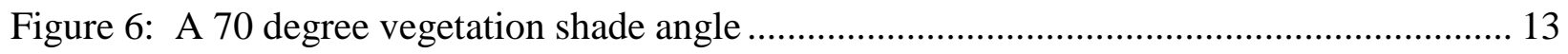

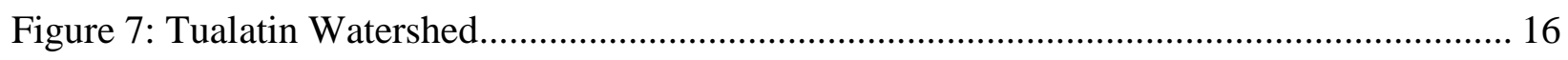

Figure 8: Tualatin River Elevation Profile...................................................................... 17

Figure 9: Hillsboro, OR Average Temperature and Rainfall................................................... 18

Figure 10: Tualatin River monthly average streamflow ..................................................... 19

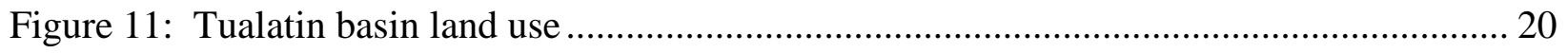

Figure 12: Tualatin River Water Management Infrastructure .............................................. 22

Figure 13: JWC Withdrawals at Spring Hill Pumping Plant .................................................. 24

Figure 14: TVID Withdrawals at Spring Hill Pumping Plant................................................ 25

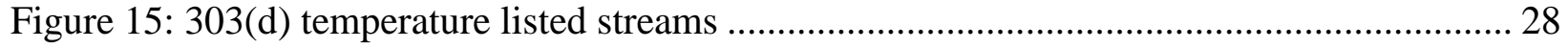

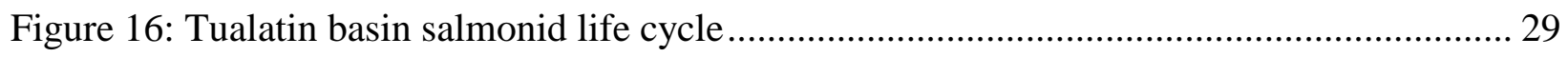

Figure 17: Tualatin basin designated fish use streams.................................................... 29

Figure 18: Tualatin basin designated salmon and steelhead spawning use streams .................. 30

Figure 19: Tualatin river flow components at West Linn gage ........................................... 32

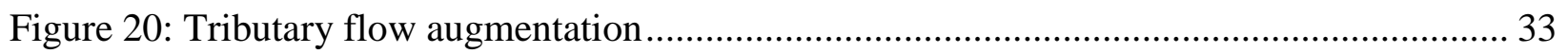

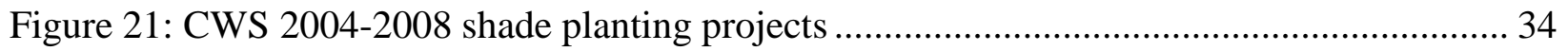

Figure 22: Streamside canopy at 2006 planting sites.......................................................... 38

Figure 23: Private and state riparian forest buffer widths.................................................. 42

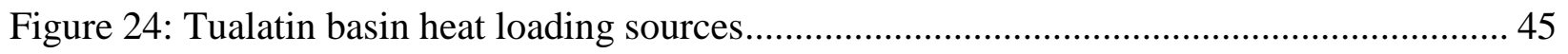

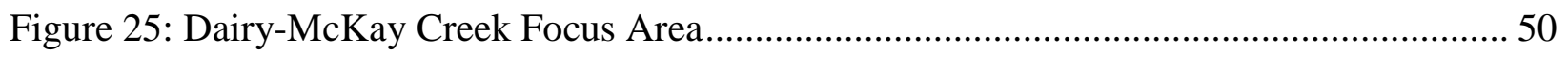

Figure 26: Projected temperatures downstream of Forest Grove WWTF NTF ....................... 53

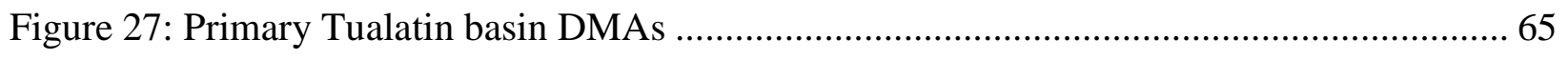

Equation 1: Stream temperature change equation (Source: DEQ 2001) ................................. 14

Table 1: Physiological effects of elevated temperatures on fish............................................ 6

Table 2: Barney Reservoir Water Allocation.......................................................................... 23

Table 3: Scoggins Reservoir Water Allocation ....................................................................... 23

Table 4: Tualatin basin 303(d) listed streams ....................................................................... 27

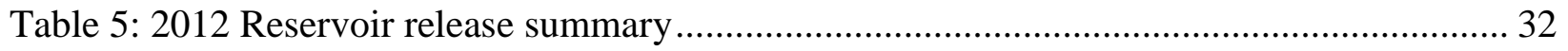

Table 6: CWS 2009-2013 shade planting banked thermal credits .......................................... 35

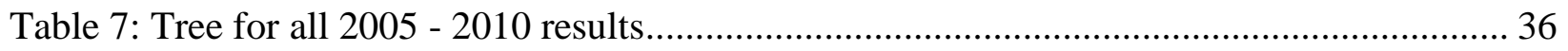


Table 8: Riparian vegetation performance measures ........................................................ 38

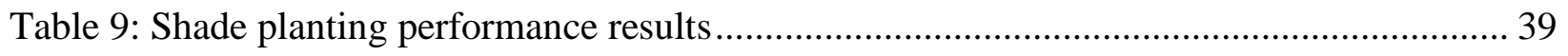

Table 10: Selected Tualatin basin stream temperatures..................................................... 44

Table 11: Projected 20 year CWS shade planting thermal load reduction ............................... 46

Table 12: Shade miles needed to offset Tualatin basin nonpoint source thermal loading .......... 47

Table 13: Nonpoint source solar radiation for major streams ............................................ 51 


\section{Appendix C: Primary Tualatin Basin DMAs and Jurisdictions}

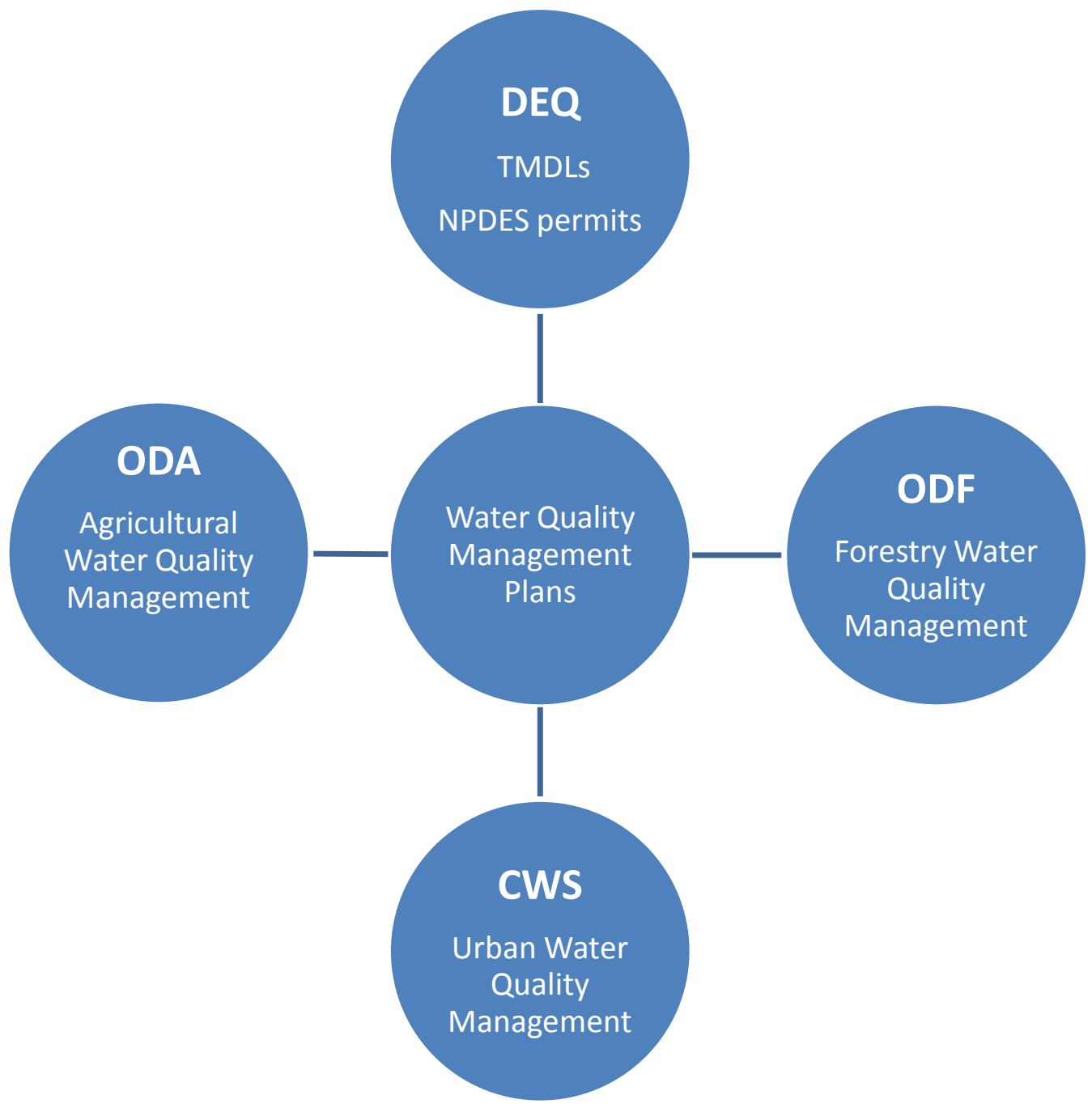

Figure 27: Primary Tualatin basin DMAs and Jurisdictions (Source: DEQ 2001) 